\title{
Interactive effects of metal pollution and temperature on metabolism in aquatic ectotherms: implications of global climate change
}

\author{
Inna M. Sokolova ${ }^{1, *}$, Gisela Lannig ${ }^{2}$ \\ ${ }^{1}$ Department of Biology, 381C Woodward Hall, University of North Carolina at Charlotte, 9201 University City Blvd., \\ Charlotte, North Carolina 28223, USA \\ ${ }^{2}$ Alfred Wegener Institute for Polar and Marine Research, Am Handelshafen 12, 27570 Bremerhaven, Germany
}

\begin{abstract}
In light of the current rising mean temperatures and fluctuations in temperature extremes involved in global climate change, a cause-and-effect understanding of the temperaturedependent impacts of additional environmental stressors on marine life is crucial for the elaboration of how marine ecosystems will shape in the future. The thermal environment plays a direct role in the distribution and survival of marine ectotherms through the temperature-dependent effects on their physiology, as well as indirectly by affecting the organism's susceptibility to other biotic and abiotic stressors. We review studies that have investigated the effects of temperature and anthropogenic pollution by trace metals, with a focus on metabolic regulation as a major mechanism that underlies the interactive effects of temperature and metals on the physiology and survival of ectotherms. These studies suggest that impairment of energy metabolism plays a key role in the synergistic effects of these stressors, and we elaborate a mechanistic framework for understanding these interactions. Furthermore, the present study seeks to provide an impetus for future investigations in order to define more precisely the physiological mechanisms and functional properties of temperature-pollution interactions.
\end{abstract}

KEY WORDS: Marine ecosystems · Global warming · Trace metals · Energy metabolism · Stress tolerance $\cdot$ Mitochondria

\section{METAL POLLUTION AND CLIMATE CHANGE}

Global climate change, which is largely driven anthropogenically, has become a dire reality in the past century, and its impact is expected to increase in the future. Recent models predict a $0.2^{\circ} \mathrm{C}$ increase in the mean global temperature per decade in the next 2 decades and a 1.8 to $4{ }^{\circ} \mathrm{C}$ increase by the year 2100 (IPCC 2007). A rise in global temperature is accompanied by increased temperature fluctuations and frequency of temperature extremes (Trenberth et al. 2007 and references therein). Global climate change is already taking its toll in the biosphere, leading to significant changes in species distribution and abundance around the globe. A less-than-exhaustive list of such recent climate-driven changes include major faunal

*Email: isokolov@uncc.edu

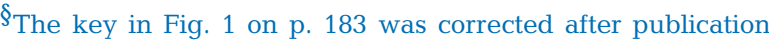
This updated version: March 16, 2021 shifts and changes in marine habitats (e.g. Beaugrand 2004), declines and shifts in zooplankton abundance (e.g. Reid et al. 1998), extensive bleaching of coral reefs (e.g. Hoegh-Guldberg 1999, Suzuki et al. 2007), local extinctions of populations (e.g. Helmuth et al. 2002), increases in mosquito-borne diseases in highlands (e.g. Martens et al. 1999), expansions of invasive species (e.g. Occhipinti-Ambrogi 2007) and the poleward shift of ranges of birds and non-migratory insects (e.g. Austin \& Rehfish 2005, La Sorte \& Thompson 2007) (for review see also Roessig et al. 2004, Parmesan 2006, Fischlin et al. 2007, Rosenzweig et al. 2007).

Aquatic ecosystems are vulnerable to the effects of global climate change, because the vast majority $(>95 \%)$ of species in aquatic realms are ectotherms (Willmer et al. 2000). Environmental temperature plays

(C) Inter-Research 2008 - www.int-res.com 
a key role in the physiology of ectotherms, as their body temperature changes with the temperature of the environment, resulting in corresponding alterations of the rates of all physiological and biochemical reactions and stability of biological molecules (Hochachka \& Somero 2002). Paleontological records, as well as the recent history of global warming, demonstrate that even modest changes in environmental temperature by a few degrees centigrade result in major shifts in ectotherm distributions and in mass extinctions of their populations (Hochachka \& Somero 2002, Gómez et al. 2008). Ectotherms are key components of aquatic food chains, spanning the range of ecological functions from primary producers to top-level consumers (Willmer et al. 2000, Begon et al. 2006); therefore, changes in population abundance and dynamics of these species due to global climate change will have profound 'ripple' effects for the whole ecosystem. Moreover, the most productive areas in aquatic realms, including freshwaters, estuaries, coastal waters and internal seas, are also those that are expected to experience the strongest impact of global warming (Willmer et al. 2000, Lozano et al. 2004).

Estuarine and coastal areas are often the most polluted areas in the ocean, due to urban development and human industrial and agricultural activities (Clark 2001, Hyun et al. 2006 and references therein; see also www.oceansatlas.com/unatlas/-ATLAS-/chapter 12f.html). Anthropogenic disturbances in these ecosystems mean that their inhabitants have to cope with multiple stressors, including pollution, hypoxia, eutrophication, etc., in addition to the temperature stress resulting from global climate change. Therefore, an understanding of the interactive effects of multiple stressors (such as pollutants and temperature) and their mechanisms is critical for predicting the tolerance limits, survival and productivity of ectotherm populations and for modeling the effects of global climate change on aquatic ecosystems (especially those with high anthropogenic pressure) around the world (Vinebrooke et al. 2004, Adams 2005).

To date, a few reviews describe the effects of temperature on endpoints such as toxicity (especially mortality), uptake and accumulation of pollutants (Cairns et al. 1975, McLusky et al. 1986, Heugens et al. 2002, Gordon 2005, Rainbow 2007). However, they do not systematically deal with the physiological background of interactions between temperature and pollutants, partially, due to the relative dearth of physiological studies on the combined effects of pollutants and temperature, and partially due to the fact that these reviews look at the broad variety of organic and inorganic pollutants that differ greatly in their mechanisms of action. As a result, an integral picture of the temperature-pollutant interaction on ectotherm physiology is hard to come by unless researchers focus on groups of pollutants with similar toxic mechanisms. Such studies would be critical for our understanding of the physiological mechanisms that limit species distribution in polluted environments in the face of global climate change, and for our ability to make generalizations beyond individual sentinel species.

Trace metals are important persistent pollutants in aquatic ecosystems worldwide and are especially prevalent in freshwater, estuarine and coastal marine ecosystems exposed to high degrees of urban pressure (Lau et al. 1998, de Mora et al. 2004, Hyun et al. 2006). Moreover, recent studies indicate that human activities significantly affect trace metal levels even in remote parts of the globe traditionally considered pristine, such as the Arctic and Antarctic (Bargagli 2000, SanchezHernandez 2000). Out of the top 20 hazardous substances on the EPA CERCLA Priority List of Hazardous Substances for 2005, 5 are metals (US Agency for Toxic Substances and Disease Registry, available at www. atsdr.cdc.gov/cxcx3.html\#bookmark02), as are $8.5 \%$ of the priority pollutants for the EPA Clean Water Act (available at http://oaspub.epa.gov/wqs/wqsi_epa_ criteria.report). Metals can accumulate in aquatic organisms and are easily transferred through the food chain to the top consumers, including humans (see Wallace \& Lopez 1996, 1997, Wallace \& Luoma 2003, Wallace et al. 2003, Fisk et al. 2005 and references therein). In some cases, such as for methylmercury (MeHg), biomagnification also occurs along the food chain, enhancing the toxic effects (Atwell et al. 1998, Campbell et al. 2005). Although the toxicity and associated health hazards of different metals may vary, many metals have common toxic cellular mechanisms and elicit similar protective responses in a wide variety of organisms (reviewed by Byczkowski \& Sorenson 1984, Roesijadi \& Robinson 1994, Wallace \& Starkov 2000, Coyle et al. 2002, Valko et al. 2005, Amiard et al. 2006).

In this review, we focus on an analysis of the current state of knowledge about the interactive effects of trace metals and temperature on the physiology of aquatic ectotherms, with emphasis on metabolic regulation and its major role in the underlying interactions between these stressors. Despite the fact that the energy costs of metal toxicity are widely debated in the literature (Sibly \& Calow 1989, Calow \& Forbes 1998, van Straalen \& Hoffmann 2000, Roff 2002), the bioenergetic aspects of temperature-metal interactions in aquatic ectotherms have not been extensively studied (see Sokolova 2004, Lannig et al. 2006, 2008 and references therein) and are only briefly (if at all) discussed in recent general treatises on mechanisms of metal toxicity (e.g. Malins \& Ostrander 1994, Walker et al. 2001, Landis \& Yu 2003, Gordon 2005). This review intends draw attention to metal toxicity and temperature- 
metal interactions. We summarize current findings and hypotheses pertaining to the bioenergetic aspects of temperature-pollution interactions and their consequences to both the metal toxicity and temperature tolerance, and create a physiological framework for understanding the mechanisms of these interactions, and we outline future research directions in this area.

\section{TEMPERATURE EFFECTS}

An observation that environmental temperature can affect tolerance to trace metals in aquatic ectotherms is one of the earliest findings in ecological toxicology (Cairns et al. 1975 and references therein). In principle, there are several potential types of temperature-toxicity relationships described for different pollutants and toxins (Fig. 1), where toxicity endpoints can be either lethal (e.g. mortality), or non lethal (e.g. decrease in physiological performance, growth rate, enzyme activity). Typically, temperature-toxicity relationships for metals follow the Type I and II curves on Fig. 1, so that elevated temperatures tend to enhance toxic effects of metals on organisms (Cairns et al. 1975, McLusky et al. 1986, Heugens et al. 2002, Gordon 2005, present review). Indeed, published studies (reviewed in Cairns et al. 1975, McLusky et al. 1986, Heugens et al. 2002, and Table 1 in the present paper) indicate that an increase in environmental temperature results in elevated mortality rates in metal-exposed ectotherms in $80 \%$ of the cases $(\mathrm{N}=118)$ (Fig. 2).

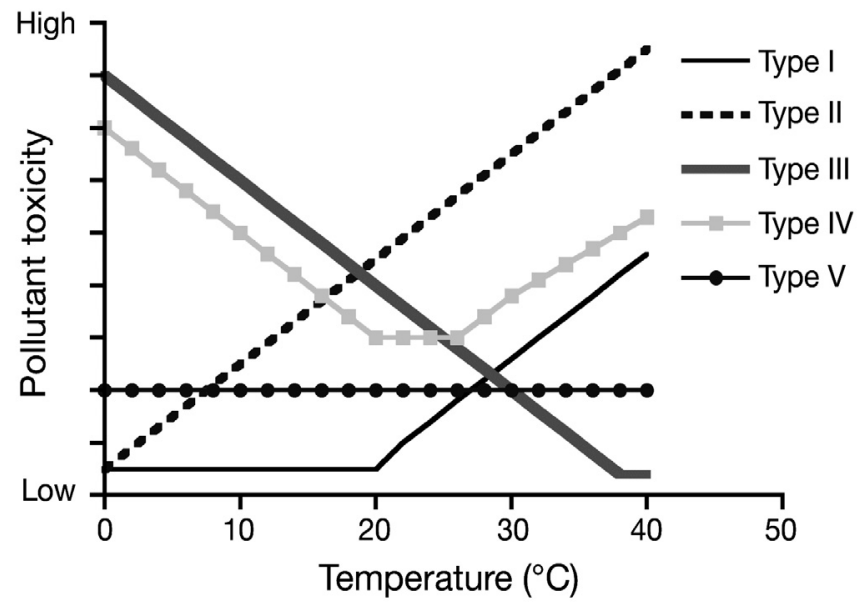

Fig. 1. General patterns of pollutant toxicity as a function of ambient temperature in aquatic ectotherms (modified and updated from Weihe 1973). Type I and II responses are the most typical for trace metals when toxicity increases with increasing temperature (see Section 2 for details). Type III response (decreasing toxicity with increasing temperature) has been described for some organic pollutants such as DDT (Cairns et al. 1975), but rarely for metals. Type IV (optimum response) is often found in mammals when pollutant or drug toxicity is minimal in the thermoneutral zone (Weihe 1973) and may be expected in stenothermal aquatic ectotherms with narrow thermal tolerance windows; however, no data exist for such organisms so far. Type V response is typical for pollutants that have constant toxicity irrespective of the temperature; this response is rarely found in aquatic ectotherms, and if temperature deviates sufficiently from the optimum, the organism is expected to respond according to Type I or Type IV curves

Table 1. Examples of the effect of environmental temperature on metal toxicity (assessed as mortality rates) in aquatic ectotherms. Temperature effect-positive: mortality increases with increasing temperature; negative: mortality decreases with increasing temperature; none: mortality does not change with temperature; optimum: mortality is minimum at the optimum temperature and increases at higher and lower temperatures. Article search was performed in Web of Science and PubMed databases using key words 'temperature' and 'metal toxicity'; only articles discussing aquatic ectotherms and not covered by the earlier reviews (Cairns et al. 1975, McLusky et al. 1986, Heugens et al. 2002) were selected for this table.

TBT: tributyltin

\begin{tabular}{|c|c|c|c|c|}
\hline & Species & Metal & Temperature effect & Source \\
\hline \multicolumn{5}{|l|}{ Vertebrates } \\
\hline Fishes & Anguilla japonica & $\mathrm{Cd}$ & Positive & Yang \& Chen (1996) \\
\hline \multicolumn{5}{|l|}{ Invertebrates } \\
\hline Plathyhelminthes & Diplostomum spathaceum & $\mathrm{Cd}, \mathrm{Zn}$ & Positive & Morley et al. (2001) \\
\hline Annelids & Tubifex tubifex & $\begin{array}{c}\mathrm{Cd}, \mathrm{Cr}, \mathrm{Pb}, \mathrm{Zn}, \mathrm{Hg}, \mathrm{Cu} \\
\mathrm{Mn}, \mathrm{Fe}\end{array}$ & $\begin{array}{l}\text { Positive } \\
\text { None }\end{array}$ & $\begin{array}{l}\text { Rathore \& Khangarot (2002) } \\
\text { Rathore \& Khangarot (2002) }\end{array}$ \\
\hline \multirow[t]{5}{*}{ Arthropods } & Tigriopus japonicus & $\mathrm{Cu}, \mathrm{Sn}(\mathrm{as} \mathrm{TBT})$ & Positive & Kwok \& Leung (2005) \\
\hline & Diaptomus clavipes & $\mathrm{Cu}$ & Positive & Boeckman \& Bidwell (2006) \\
\hline & Daphnia pulex & $\mathrm{Cu}$ & None & Boeckman \& Bidwell (2006) \\
\hline & Daphnia magna & $\begin{array}{l}\mathrm{Hg} \\
\mathrm{Cr} \\
\mathrm{Cd}\end{array}$ & $\begin{array}{l}\text { Positive } \\
\text { Positive } \\
\text { Positive }\end{array}$ & $\begin{array}{l}\text { Tsui \& Wang (2006) } \\
\text { Martínez-Jerónimo et al. (2006) } \\
\text { Heugens et al. (2003) }\end{array}$ \\
\hline & Orconectes immunis & $\mathrm{Cu}, \mathrm{Cd}, \mathrm{Zn}, \mathrm{Pb}$ & Positive & Khan et al. (2006) \\
\hline Mollusks & Gammarus pulex pulex & $\mathrm{Cu}, \mathrm{Zn}, \mathrm{Pb}$ & Positive & Bat et al. (2000) \\
\hline
\end{tabular}




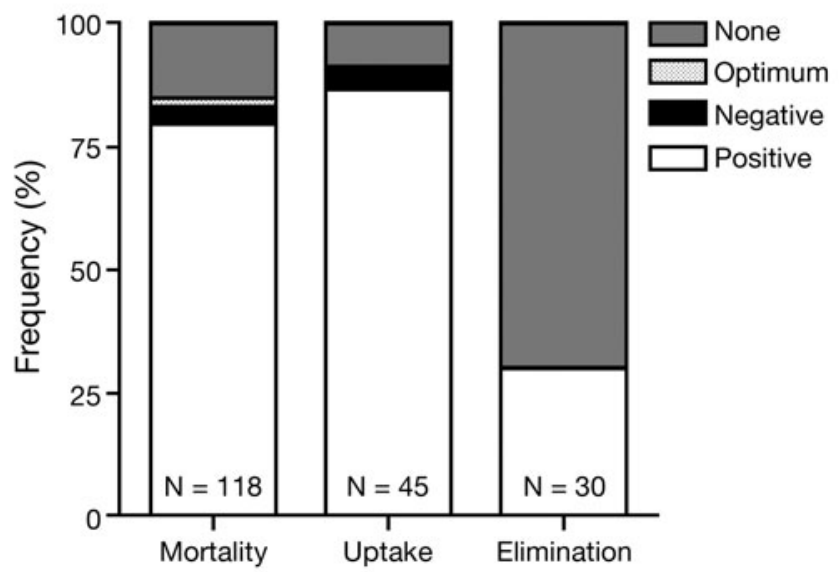

Fig. 2. Temperature effects on uptake/accumulation, elimination and toxicity (measured as mortality) of trace metals in aquatic ectotherms. Frequencies of occurrence of different types of correlations between environmental temperature and the respective endpoint are given in percentage. Positive: uptake or accumulation (U), elimination (E), or mortality (M) increase with temperature; negative: $\mathrm{U}, \mathrm{E}$ or $\mathrm{M}$ decrease with temperature; optimum: $\mathrm{U}$ or $\mathrm{M}$ is minimal (or $\mathrm{E}$ is maximal) at the optimal temperature and rises (or for $\mathrm{E}$, declines) as the temperature increases or decreases; none: no correlation observed between temperature and the respective endpoint. Based on Cairns et al. 1975, McLusky et al. 1986, Heugens et al. 2002, and Tables 1 to 3 of the present paper

The elevated toxicity of metals at higher temperatures may be partially explained by the higher uptake rate (and thus high internal concentrations) of metals. Typically, the rates of metal uptake and accumulation increase with increasing temperature (Cairns et al. 1975, McLusky et al. 1986, Hutchins et al. 1996, Heugens et al. 2002, and Table 2 of the present review). $Q_{10}$ for metal uptake ranges between 3 and 5, occasionally up to 7 to 12 (meaning a 3 - to 5-fold and 7 - to 12 -fold increase in uptake rate, respectively, with every $10^{\circ} \mathrm{C}$ increase in environmental temperature [Hutchins et al. 1996]). Indeed, metal uptake and accumulation were strongly elevated at high temperatures in $>85 \%$ of all studies analyzed for this review (Fig. 2), covering a broad variety of aquatic organisms from protozoans to flatworms and vertebrates, suggesting that highly conserved physiological and cellular processes underlie the temperature-dependent increase in metal uptake and accumulation.

Bioavailability of metals may strongly affect their uptake and toxicity in aquatic organisms (Rainbow 2007). Dissolved free metal ions are the most bioavailable form in aquatic environments, with the fastest rate of uptake and accumulation in organisms (Luoma 1983, Worms et al. 2006). In principle, the environmental temperature can affect the bioavailability of metals due to the higher solubility of metal compounds, and thus higher concentrations of free metal ions, at ele- vated temperatures. However, empirical data, as well as 2 widely used models (the free ion activity model and the biotic ligand model), show that temperature in the environmentally relevant ranges has a negligible effect on metal speciation, particularly on free ion activity (Luoma 1983, Bervoets \& Blust 1999, Hassler et al. 2004). Therefore, the biological effects of temperature need to be taken into account in order to explain its effect on metal uptake and accumulation.

In principle, several biological factors can affect temperature-dependent changes in metal uptake and/or elimination, including metal transport, membrane permeability and systemic functions (such as ventilation or absorption from food) that can influence the degree of exposure of permeable epi- and endothelia to metals. Cellular pathways for the uptake and elimination of metal ions in the cell include passive diffusion across cell membranes, facilitated transport, active transport by ion channels, and endocytosis (for recent reviews on metal transport mechanisms see Ponka et al. 1998, Rolfs \& Hediger 1999, Wood et al. 1999, Zalups \& Ahmad 2003, Kambe et al. 2004, Balamurugan \& Schaffner 2006). Uptake rates by passive diffusion are low for most dissolved metals because their charges and hydration shells make them poorly soluble in lipid membranes; the few exceptions are metallo-organic complexes such as MeHg or tributyltin (TBT) (Roesijadi \& Robinson 1994, Walker et al. 2001). Moreover, temperature-dependent changes in diffusion coefficients are usually small, and typical $Q_{10}$ values for passive diffusion are in the range of 1.03 to 1.40 (Willmer et al. 2000), which does not sufficiently explain the temperature dependency of metal uptake rates in most organisms (Bervoets et al. 1996, Hutchins et al. 1996). Similarly, receptor-mediated endocytosis plays a limited role in the uptake of trace metals, with an exception of some essential metals such as iron (Roesijadi \& Robinson 1994, Ponka et al. 1998). Active ATPdependent transport via ion pumps and facilitated diffusion via ion channels are by far the predominant routes of metal uptake in aquatic organisms (Roesijadi \& Robinson 1994, Rolfs \& Hediger 1999, Wood et al. 1999, Zalups \& Ahmad 2003, Kambe et al. 2004, Balamurugan \& Schaffner 2006), which, in ectotherms, are strongly affected by the environmental temperature. Indeed, the apparent activation energies $\left(E_{\mathrm{a}}\right)$ for metal uptake are typically much higher than activation energies for free diffusion and are close to $E_{\mathrm{a}}$ for respiration and active ion transport (Bervoets et al. 1996, Hutchins et al. 1996). Therefore, a rise in temperature will result in a profound increase in metal uptake rates and, unless counteracted by a similar increase in elimination rates, an elevated accumulation of metals in the organism.

An increase in metabolic rates at elevated temperatures may contribute to metal accumulation in ectotherms due to a higher energy demand. This increased 
Table 2. Examples of the effect of environmental temperature on metal uptake and accumulation in aquatic ectotherms. Temperature effect-positive: uptake/accumulation increases with increasing temperature; negative: uptake/accumulation decreases with increasing temperature; none: uptake/accumulation does not change with the temperature. Unless otherwise indicated, uptake/accumulation of waterborne metals by whole organisms is presented. An article search was performed in Web of Science and PubMed databases using key words 'temperature' and ('metal uptake' or 'metal accumulation'); only articles discussing aquatic ectotherms and not covered by the earlier reviews (Cairns et al. 1975, McLusky et al. 1986, Heugens et al. 2002) were selected for this table

\begin{tabular}{|c|c|c|c|c|c|}
\hline & Species & Metal & $\begin{array}{l}\text { Temperature } \\
\text { effect }\end{array}$ & $\begin{array}{l}\text { Uptake or } \\
\text { accumulation }\end{array}$ & Source \\
\hline \multicolumn{6}{|l|}{ Vertebrates } \\
\hline \multirow[t]{5}{*}{ Fishes } & Oncorhynchus mykiss & $\mathrm{Ag}$ & Positive & $\begin{array}{c}\text { Uptake, } \\
\text { accumulation }\end{array}$ & Nichols \& Playle (2004) \\
\hline & Salmo gairdneri & $\mathrm{Hg}$ & Positive & Accumulation & McLeod \& Pessah (1973) \\
\hline & & $\mathrm{Cd}$ & Positive & Accumulation & Roch \& Maly (1979) \\
\hline & Lepomis macrochirus & $\mathrm{Cu}$ & Positive & Accumulation & Felts \& Heath (1984) \\
\hline & Anguilla japonica & $\mathrm{Cd}$ & Positive & Accumulation & Yang \& Chen (1996) \\
\hline \multicolumn{6}{|l|}{ Invertebrates } \\
\hline \multirow[t]{13}{*}{ Mollusks } & Saccostrea echinata & $\mathrm{Cd}, \mathrm{Zn}$ & Positive & Accumulation & Denton \& Burton-Jones (1981) \\
\hline & Crassostrea virginica & $\mathrm{Cd}$ & None & Accumulation & Lannig et al. (2006) \\
\hline & & $\mathrm{Cd}$ & Positive & Accumulation & Cherkasov et al. (2007) \\
\hline & Mytilus edulis & $\mathrm{Cd}$ & Positive & Accumulation & Phillips (1976) \\
\hline & & $\mathrm{Cd}, \mathrm{Co}, \mathrm{Zn}$ & Positive & Uptake & Baines et al. (2005) \\
\hline & & $\mathrm{Ag}, \mathrm{Am}$ & None & Uptake & Baines et al. (2005) \\
\hline & & $\mathrm{Cd}$ & Positive & Accumulation & Fischer (1986) \\
\hline & & $\mathrm{Cd}, \mathrm{Pb}$ & Positive & Uptake & Mubiana \& Blust (2007) \\
\hline & & $\mathrm{Cu}$ & Negative & Uptake & Mubiana \& Blust (2007) \\
\hline & & Co & None & Uptake & Mubiana \& Blust (2007) \\
\hline & (isolated gills) & $\mathrm{Cd}, \mathrm{Pb}, \mathrm{Cu}, \mathrm{Co}$ & Positive & Uptake & Mubiana \& Blust (2007) \\
\hline & Nucella lapillus & $\mathrm{Cd}$ & Positive & Accumulation & Leung et al. (2000) \\
\hline & Perna viridis & $\mathrm{Cd}, \mathrm{Zn}$ & Positive & Uptake & Wang et al. (2005) \\
\hline \multirow[t]{6}{*}{ Arthropods } & Callinectes sapidus & $\mathrm{Cd}$ & Positive & Accumulation & Hutcheson (1974) \\
\hline & Daphnia magna & $\mathrm{Cd}$ & Positive & Accumulation & Heugens et al.(2003) \\
\hline & & $\mathrm{Hg}$ & Positive & Uptake & Tsui \& Wang (2006) \\
\hline & $\begin{array}{l}\text { Chironomus riparius } \\
\text { (larvae) }\end{array}$ & $\mathrm{Cd}, \mathrm{Zn}$ & Positive & Uptake & $\begin{array}{l}\text { Bervoets et al. (1996), Bervoets } \\
\text { \& Blust (1999) }\end{array}$ \\
\hline & Hexagenia rigida (larvae) & $\mathrm{MeHg}$ & Positive & Accumulation & Odin et al. (1996) \\
\hline & & Cd & Negative & Accumulation & Odin et al. (1996) \\
\hline Echinoderms & Ophiothrix fragilis & $\begin{array}{c}\mathrm{Ag}, \mathrm{Am}, \mathrm{Ba} \\
\mathrm{Cd}, \mathrm{Co}, \mathrm{Cs}, \mathrm{Eu}, \\
\mathrm{Mn}, \mathrm{Ru}, \mathrm{Zn}\end{array}$ & Positive & Uptake & Hutchins et al. (1996) \\
\hline Chlorophyta & Chlorella vulgaris & $\mathrm{Cu}$ & Positive & Uptake & Mehta et al. (2002) \\
\hline
\end{tabular}

demand results in elevated ventilation and/or feeding rates (Willmer et al. 2000, Pörtner 2001, 2002), which in turn lead to higher exposure to metal-contaminated water or food. Moreover, metal contamination can damage the respiratory surfaces in aquatic ectotherms such as fish, crustaceans and bivalves, resulting in a less efficient oxygen uptake and an associated higher need for active ventilation (Spicer \& Weber 1991, Nonnotte et al. 1993, Wilson \& Taylor 1993, Hebel et al. 1997, Leung et al. 2000 and references therein). For example, the proportion of time spent actively ventilating increased with increasing temperatures and $\mathrm{Cd}$ expo- sure in eastern oysters Crassostrea virginica; at $20^{\circ} \mathrm{C}$ oysters spent about $30 \%$ of time actively ventilating, whereas at $28^{\circ} \mathrm{C}$ oysters exposed to Cd spent $>70 \%$ of time ventilating (Lannig et al. 2006). Cd and Zn uptake rates were closely correlated with the rate of oxygen consumption $\left(\mathrm{MO}_{2}\right)$ and ventilation rates in green mussels Perna viridis over a wide range of environmental temperatures and $\mathrm{O}_{2}$ partial pressures (Wang et al. 2005). Other studies in bivalves also demonstrate that ventilatory activity may be a rate-limiting step in metal uptake in these organisms (Massabuau \& Tran 2003). In fish, such as bluegills and rainbow trout, high venti- 
lation rates at elevated temperatures also resulted in higher uptake of metals such as $\mathrm{Cd}, \mathrm{Cu}$ and $\mathrm{Hg}$ (McLeod \& Pessah 1973, Roch \& Maly 1979, Felts \& Heath 1984). Temperature effects on metal uptake from food have been less extensively studied (Roesijadi \& Robinson 1994, Baines et al. 2005). Given the high transfer rate of trace metals across digestive tract epithelia (Baines et al. 2005, Cooper et al. 2006, Croteau et al. 2007 and references therein), a dietary uptake of metals may represent an important exposure route for aquatic ectotherms, and temperaturedependent changes in food intake and absorption may play a key role in metal accumulation, toxicity and food web transfer and thus require further investigation.

The effect of temperature on membrane permeability to metal ions represents another intriguing mechanism that may contribute to elevated metal uptake by aquatic ectotherms. An acute change in ambient temperature results in a change in membrane fluidity and local transitions of the lipid bilayer between the sol and gel phases, which can affect membrane integrity and permeability, as well as the mobility and function of membrane-associated receptors, transport and channel proteins (Hazel 1995, Hochachka \& Somero 2002). If the temperature change persists, membrane structure and properties may change in the long term, in order to counteract alterations in membrane order (Hazel 1995, Hochachka \& Somero 2002). Usually, adaptation or acclimation to low temperatures results in an increase in the content of phospholipids with unsaturated acyl chains, a decrease in the ratio of phosphatidyl choline to phosphatidyl ethanolamine and a decline in cholesterol content in the membrane, all making the membrane more fluid (less viscous) (Hazel 1995, Hochachka \& Somero 2002). Acclimation or adaptation to high temperatures leads to the opposite changes in phospholipid and cholesterol structure and content (Hazel 1995, Hochachka \& Somero 2002). These homeostatic changes, first described by Sinensky (1974), are often referred to as homeoviscous adaptation, emphasizing that their net effect is to maintain the optimum level of fluidity compatible with the normal function of the membrane and associated structures (Hazel 1995, Yang \& Hwang 1996, Crockett 1998, Farkas et al. 2001). Potentially, homeoviscous adaptation in aquatic ectotherms during long-term temperature change (e.g. due to seasonality or adaptation to different climates), as well as acute alterations of membrane fluidity during short-term (e.g. diurnal or tidal) temperature fluctuations, can have profound effects on membrane permeability (Williams \& Somero 1996, Hall et al. 2002, Pernet et al. 2007) affecting metal uptake; however, this aspect of membrane physiology has not been extensively explored and would represent a fruitful avenue for further investigations.
Temperature effects on metal elimination in aquatic ectotherms have been less extensively studied than metal uptake, and available data suggest that these effects are less important and profound than temperature effects on the uptake (Cairns et al. 1975, McLusky et al. 1986, Heugens et al. 2002, Gordon 2005, Table 3 in the present review). Indeed, most studies detected only a weak temperature dependence of metal elimination, and in most cases elimination rates were temperatureindependent in the environmental range (Fig. 2). Mechanisms of metal elimination in aquatic ectotherms are not well understood. In principle, they may involve passive and active processes similar to metal uptake (Roesijadi \& Robinson 1994, Rainbow 2007); however, relative contributions of specific cellular mechanisms to metal elimination and detoxification may differ from those involved in the uptake and require further investigation. As a result of differences in temperature sensitivity of metal uptake and elimination, the net accumulation of metals (and thus internal effective concentrations) increases with elevated temperatures, resulting in higher toxicity (Rainbow 2007). Metal toxicity is determined mostly by the amount of bioavailable metals in the metabolically accessible pool, as well as by the total body burden of the metals (Rainbow 2007). Thus, it is conceivable that environmental temperature can affect metal toxicity without changing the total amount of accumulated metals in the body, if the temperature change results in redistribution of metals between metabolically available (and thus potentially toxic) and unavailable pools (i.e. detoxified or removed to places of long-term storage) (Rainbow 2007). Currently, there are no studies on the effects of environmental temperature on metal distribution between different sub-cellular compartments and/or body organs (e.g. those involved in metal storage vs. metabolism), and this suggestion is speculative at present. It is especially interesting in view of the fact that in some organisms elevated temperatures often appear to result in increased intrinsic sensitivity to metals (i.e. higher toxicity at the same internal concentrations) at elevated temperatures. For example, in rainbow trout, seasonal warming resulted in increased summer mortality without any change in the pollutant concentration $(\mathrm{Hg})$ in the water (McLeod \& Pessah 1973). In freshwater crustaceans Daphnia magna, median and threshold lethal body burdens of $\mathrm{Hg}$ and $\mathrm{Cd}$ decreased with increasing temperature, implying that lower tissue metal burdens were required to kill daphnids at higher temperatures (Heugens et al. 2003, Tsui \& Wang 2006). Similarly, in eastern oysters Crassostrea virginica, exposure to $\mathrm{Cd}$ at an elevated temperature $\left(28^{\circ} \mathrm{C}\right)$ resulted in a significant increase in mortality compared to 20 or $24^{\circ} \mathrm{C}$ despite similar tissue Cd burdens at all experimental temperatures (Lannig et al. 2006). Physiological mechanisms 
Table 3. Examples of the effects of environmental temperature on metal elimination in aquatic ectotherms. Temperature effectpositive: elimination increases with increasing temperature; negative: elimination decreases with increasing temperature; none: elimination does not change with the temperature. Article search was performed in Web of Science and PubMed databases using key words 'temperature' and 'metal elimination'; only articles discussing aquatic ectotherms and not covered by the earlier reviews (Cairns et al. 1975, McLusky et al. 1986, Heugens et al. 2002) were selected for this table

\begin{tabular}{|c|c|c|c|c|}
\hline & Species & Metal & Temperature effect & Source \\
\hline \multicolumn{5}{|l|}{ Vertebrates } \\
\hline \multirow[t]{3}{*}{ Fishes } & Oncorhynchus mykiss & $\mathrm{Ag}$ & None & Nichols \& Playle (2004) \\
\hline & Noemachelius barbatulus & $\mathrm{Cd}$ & Positive & Douben (1989) \\
\hline & Salmo trutta & Cs & Positive & Ugedal et al. (1992) \\
\hline \multicolumn{5}{|l|}{ Invertebrates } \\
\hline \multirow[t]{2}{*}{ Arthropods } & Daphnia magna & $\mathrm{Cd}$ & None & Heugens et al. (2003) \\
\hline & Hexagenia rigida (larvae) & $\mathrm{Cd}$ & Positive & Odin et al. (1996) \\
\hline \multirow[t]{6}{*}{ Mollusks } & Corbicula fluminea & $\mathrm{Hg}, \mathrm{Cd}$ & None & Inza et al. (1998) \\
\hline & Mytilus edulis & $\mathrm{Cd}, \mathrm{Co}, \mathrm{Pb}$ & None & Mubiana \& Blust (2007) \\
\hline & & $\mathrm{Cu}$ & Positive & Mubiana \& Blust (2007) \\
\hline & & $\mathrm{Ag}, \mathrm{Am}, \mathrm{Cd}, \mathrm{Zn}$ & Positive & Baines et al. (2006) \\
\hline & & Co & None & Baines et al. (2006) \\
\hline & Macoma balthica & $\mathrm{Am}, \mathrm{Co}, \mathrm{Cs}$ & None & Hutchins et al. (1998) \\
\hline Echinoderms & Ophiothrix fragilis & $\begin{array}{c}\mathrm{Ag}, \mathrm{Am}, \mathrm{Ba}, \mathrm{Cd} \\
\mathrm{Co}, \mathrm{Cs}, \mathrm{Eu}, \mathrm{Mn}, \mathrm{Ru}, \mathrm{Zn}\end{array}$ & None & Hutchins et al. (1996) \\
\hline
\end{tabular}

explaining elevated intrinsic sensitivity to trace metals at high temperatures are not fully understood and may include an increased sensitivity to metals by intracellular structures such as mitochondria and enzymes (Sokolova 2004, Ivanina et al. 2008b), elevated energy misbalance due to increased detoxification and maintenance costs (see Section 3), the redistribution between metabolically available and inert metal pools as suggested by Rainbow (2007), or a combination of these factors. Irrespective of the exact mechanisms, an increased accumulation and toxicity of metals due to elevated temperatures can have important physiological and ecological consequences in aquatic ectotherms, affecting their survival and performance by changing effective concentrations of metals in their tissues an exposure and vulnerability of target organs/systems (Heugens et al. 2003, Tsui \& Wang 2006, Rainbow 2007), and potentially resulting in local decreases in abundance and/or extinction of affected populations, and altered transfer rates of metals through the food web (Wallace et al. 2003, Gordon 2005).

\section{METABOLIC ASPECTS}

Energy metabolism can be regarded as a key target for the stress effects of temperature and toxic metals, due to the key role of energy balance in stress adaptation and tolerance (Sibly \& Calow 1989, Calow \&
Forbes 1998, Roff 2002). Indeed, the survival of an organism under stress conditions crucially depends on its ability to balance energy demand and energy supply (Sibly \& Calow 1989, Calow \& Forbes 1998, Roff 2002). The minimum requirement for short-term survival is provision of sufficient energy to cover basal maintenance needs such as maintenance of cellular homeostasis and systemic functions, including ventilation and circulation (Sibly \& Calow 1989, Calow \& Forbes 1998, Pörtner 2001). On a long-term basis (especially on the time scale required for population survival), additional energy is needed to cover other costs, such as reproduction, growth, locomotion (to escape predators, to find food or a mate), etc. (for review see Pörtner 2001). Environmental stressors such as exposure to toxic metals and sub- or supra-optimal temperatures can shift this fine-tuned balance, resulting in energy deficits due to elevated maintenance costs (e.g. for detoxification or repair of the cellular damage by toxins or stressful temperatures) or direct interference with energy conservation (e.g. mitochondrial function and/or cytosolic ATP-producing pathways) (Sibly \& Calow 1989, Calow \& Forbes 1998, Pörtner 2001, see also Sections 3.1 and 3.2 below). In either case, such shifts in the energy balance may lead to costs and trade-offs at the whole-organism and population levels, resulting in decreased production, elevated mortality and, in extreme cases, local extinctions. 
Despite the indubitable importance of bioenergetics in survival under metal and temperature stress, the role of interactive effects of these 2 stressors in energy metabolism has not been extensively explored. Below we critically review the literature on the metabolic effects of temperature-metal interactions and propose approaches that could lead to development of a testable conceptual model that explains how the interactions of elevated temperature and heavy metal exposure can affect/impair aerobic energy metabolism in aquatic ectotherms.

\subsection{Energy demand}

The effects of elevated temperature on the metabolic rate and energy demand of aquatic ectotherms has been extensively studied and summarized in excellent reviews (Pörtner 2001, 2002, Hochachka \& Somero 2002 and references therein). Within the thermal tolerance range, a rise in temperature results in a proportional increase in different aspects of the standard metabolic rate, including costs of protein synthesis, ATP turnover, mitochondrial proton leak and nonmitochondrial respiration (Cherkasov et al. 2006a). Beyond the tolerance range at the pejus and upper critical temperatures, some cellular maintenance costs (especially costs of mitochondrial maintenance due to the proton leak) may increase disproportionately at the expense of other cellular functions (Pörtner 2001).

Exposure to toxic metals may also result in an increased basal metabolic demand (i.e. the amount of metabolic energy required for the basal maintenance and survival of the individual) (Sibly \& Calow 1989, Calow \& Forbes 1998); however, unlike temperature, metal exposures typically lead to a disproportionate increase in the aspects of cell metabolism responsible for cellular detoxification and repair (Sibly \& Calow 1989, Calow \& Forbes 1998, Cherkasov et al. 2006a, Ivanina et al. 2008a). Our studies showed that both protein synthesis rate and oxygen consumption required to cover the costs of protein synthesis increased in eastern oysters Crassostrea virginica exposed to Cd (Cherkasov et al. 2006a, Ivanina et al. 2008a). An increase in the cellular protein synthesis in metal-exposed oysters was associated with an elevated expression of cellular protection proteins, such as metallothioneins, P-glycoproteins and heat shock proteins (Ivanina \& Sokolova 2008, Ivanina et al. 2008a). Similarly, yellow perch Perca flavescens from metal-contaminated lakes had significantly higher liver biosynthetic capacity (as shown by elevated activity of nucleotide diphosphate kinase), indicating that elevated protein synthesis is involved in the protective response against metals in the field (Couture \& Kumar 2003). Induction of metallothioneins is a hallmark response to metal exposure (Bauman et al. 1993, Roesijadi 1996), and heat shock proteins (HSP) are also commonly up-regulated in metal-exposed animals (reviewed by Feder \& Hoffman 1999). Elevated synthesis of cellular protection proteins may contribute to elevated standard metabolic rates and maintenance costs in metal-exposed ectotherms. According to some estimates, stress proteins can represent up to $7 \%$ of the total protein pool with increasing contribution during stressful conditions (Kultz 2003), and the synthesis rate of HSPs is comparable to some housekeeping genes such as actin, even under non-stress conditions (Lanks 1983). Metallothionein synthesis may account for up to $5 \%$ of the total metabolic rate in metal-challenged organisms (Barber et al. 1990). Given that total protein synthesis typically accounts for 10 to $20 \%$ of the standard metabolic rate (Hand \& Hardewig 1996, Cherkasov et al. 2006a), metallothionein and HSP synthesis may represent a significant additional cost to the organism, diverting energy from essential functions such as growth, reproduction and immunity toward metal detoxification and damage repair.

Other protective mechanisms, such as glutathione expression, antioxidants, or cellular repair mechanisms, may also contribute to the elevated maintenance costs in metal-exposed organisms. Elevated glutathione expression is a common response to low (sublethal) metal levels (Viarengo et al. 1990, Ringwood et al. 1999, Mitchelmore et al. 2003, Regoli et al. 2004, Lannig et al. 2006) and has been proposed to aid detoxification by binding the toxic free ion form of metals, although at high metal levels this response may be impaired and gluthathione depletion ensues (Regoli \& Principato 1995, Ringwood et al. 1998, Mitchelmore et al. 2003, Toplan et al. 2003). Notably, our studies show that temperature can affect this response in aquatic ectotherms; thus, glutathione levels increased in oysters during long-term $\mathrm{Cd}$ exposure at 20 and $24^{\circ} \mathrm{C}$, but not at $28^{\circ} \mathrm{C}$, indicating that this protective response was impaired at elevated temperatures (Lannig et al. 2006). The expression of mitochondrial Lon protease, a multifunctional enzyme that degrades damaged proteins and naturally short-lived proteins, was also up-regulated in Cdstressed oysters, indicating higher protein turnover in their mitochondria, possibly to degrade Cd-damaged proteins (Sanni et al. 2007). Interestingly, Lon protease expression tended to be lower in $28^{\circ} \mathrm{C}$-acclimated oysters than in $12^{\circ} \mathrm{C}$ - or $20^{\circ} \mathrm{C}$-acclimated ones (Sanni et al. 2007), suggesting that elevated temperature can negatively affect protein quality control systems in oyster mitochondria, contributing to the above-described decline in mitochondrial capacity in $\mathrm{Cd}$ - and heatstressed oysters. Overall, the interactive effects of temperature and metal stress on antioxidants and cellular repair mechanisms have not been extensively studied 
in ectotherms and require further investigation to determine whether similar limitations of protective response at high temperatures apply.

High energy demand in metal-exposed aquatic ectotherms is further supported by depletion of body energy stores during metal exposures, especially when combined with elevated temperatures. Thus, in oysters Crassostrea virginica, simultaneous exposure to elevated temperatures and $\mathrm{Cd}$ resulted in a significant depletion of glycogen stores, whereas each of these 2 stressors alone had no effect on tissue glycogen content (Lannig \& Sokolova unpubl. data). Depletion of body glycogen and/or lipid reserves was also observed in fishes (sea bass Dicentrarchus labrax and rainbow trout Oncorhynchus mykiss), gastropods (dogwhelk Nucella lapillus) and crustaceans (crabs Scylla serrata and the harpacticoid Tigriopus japonicus) exposed to $\mathrm{Cd}, \mathrm{Cu}$ and/or tributyltin (TBT) (Reddy \& Bhagya- lakshmi 1994, Cattani et al. 1996, Clearwater et al. 2002, Kwok \& Leung 2005). At high concentrations of $\mathrm{Cu}$ and TBT, T. japonicus entered a metabolically dormant state enhancing their survival (Kwok \& Leung 2005), showing that an ability to channel energy into coping with toxins (even at the expense of other biological functions) may be essential in survival of metal exposures.

It is worth noting that the literature on the effects of metals on metabolic rates in aquatic ectotherms reveals a complicated and seemingly controversial picture with the rates of metabolism increasing, decreasing, or not changing in metal-exposed organisms (see Table 4 and text below for references). In general, the degree and direction of metal effects on aerobic metabolism (measured as the rate of oxygen consumption) depend on the metal, its concentration and exposure regime (acute or chronic). Typically, chronic ex-

Table 4. Effects of metals on aerobic metabolic rates in aquatic ectotherms. Metal effects — positive: metabolic rates increase in metal-exposed organisms; negative: metabolic rates decrease in metal-exposed organisms; none: metabolic rates do not change in metal-exposed organisms. $\dot{M O}_{2}$ defines whether standard (reflecting energy demand for basal maintenance), routine (energy demand for basal maintenance plus costs of non-quantified routine activity), active (energy demand for basal maintenance plus costs of maximum aerobic performance) metabolic rates were determined in a particular study. Question mark (?) indicates that the metabolic rate could not be classified as standard, routine, or active due to insufficient data presented in this paper. Article search was performed in Web of Science and PubMed databases using keywords 'metal' ('metabolic rate' or 'oxygen consumption'); only articles discussing aerobic metabolism in aquatic ectotherms were selected

\begin{tabular}{|c|c|c|c|c|c|}
\hline & Species & Metal & $\dot{\mathrm{MO}}_{2}$ & Metal effect & Source \\
\hline \multicolumn{6}{|c|}{ Vertebrates } \\
\hline \multirow[t]{3}{*}{ Fishes } & Salmo gairdneri & $\mathrm{Cu}$ & Active & Negative & Waiwood \& Beamish (1978) \\
\hline & Perca flavescens & $\mathrm{Cu}, \mathrm{Cd}$ & Post-active $^{a}$ & Negative & Couture \& Kumar (2003) \\
\hline & Cyprinus carpio & $\mathrm{Cd}$ & Routine & $\begin{array}{l}\text { Negative }^{\mathrm{b}} \\
\text { Positive }^{\mathrm{c}}\end{array}$ & Suresh et al. (1993) \\
\hline \multicolumn{6}{|c|}{ Invertebrates } \\
\hline \multirow[t]{9}{*}{ Crustace } & Orco & onectes immuni & $\mathrm{Cu}$ & $\begin{array}{l}\text { Routine } \\
\text { Negative }^{\mathrm{e}}\end{array}$ & Positive $^{\mathrm{d}}$, Khan et al. (2006) \\
\hline & & $\mathrm{Cd}, \mathrm{Zn}, \mathrm{Pb}$ & Routine & Negative $^{\mathrm{f}}$ & Khan et al. (2006) \\
\hline & Callinectes similis & hromium (Cr) & Routine & Negative & Ramirez et al. (1989) \\
\hline & & $\mathrm{Cd}$ & Routine & $\begin{array}{l}\text { Positive }^{g} \\
\text { None }^{\mathrm{h}}\end{array}$ & Ramirez et al. (1989) \\
\hline & Cherax destructor & Lead $(\mathrm{Pb})$ & Routine & Negative & Ahern \& Morris (1999) \\
\hline & Palaemon elegans & $\mathrm{Cd}, \mathrm{Cr}$ & $?$ & Positive & Moraitou-Apostoloupoulou et al. (1982) \\
\hline & Tisbe holothuriae & $\mathrm{Cu}$ & $?$ & Positive & Moraitou-Apostoloupoulou et al. (1983) \\
\hline & Acartia clausa & $\mathrm{Cu}, \mathrm{Cd}, \mathrm{Cr}$ & $?$ & Positive & Moraitou-\& Verriopoulos (1979) \\
\hline & Farfantepenaeus paulensis & $\mathrm{Cu}, \mathrm{Zn}$ & $?$ & Negative & Santos et al. (2000) \\
\hline \multirow[t]{4}{*}{ Mollusks } & Crassostrea virginica & $\mathrm{Cd}$ & Standard & Positive & Lannig et al. (2006) \\
\hline & Ruditapes decussatus & $\mathrm{Cd}$ & Standard & Positive & Baghdiguian \& Riva (1985) \\
\hline & Hemifusus tuba & Arsenic & Routine & None & Depledge \& Phillips '(1987) \\
\hline & Perna viridis & r, silver (Ag) & Routine & Negative & Vijayavel et al. '(2007) \\
\hline
\end{tabular}


posures to low (environmentally relevant) metal levels either do not affect respiration rate of aquatic organisms or result in elevated rates of oxygen uptake (Moraitou-Apostolopoulou \& Verriopoulos 1979, Moraitou-Apostolopoulou et al. 1982, Baghdiguian \& Riva 1985, Ramirez et al. 1989, Lannig et al. 2006 and references therein). In contrast, acute exposures to high metal concentrations usually lead to a decline in the rates of oxygen uptake (Abdullah \& Ireland 1986, Ramirez et al. 1989, Spicer \& Weber 1991, Cheung \& Wong 1998, Leung et al. 2000, Rao \& Khan 2000 and references therein). Generalizations of the metabolic effect of metals and temperature-metal interactions are further complicated by the current lack of a standardized approach to $\dot{\mathrm{MO}}$ 2 determination in toxicological studies of aquatic ectotherms. Indeed, different studies measured the effects of metal exposure on standard metabolic rates, routine metabolic rates, or active metabolic rates, each of which would predictably respond differently to metal exposure and temperature stress. While metal exposure is expected to elevate the rates of standard (basal) metabolism due to higher maintenance costs for detoxification and damage repair, its effects on routine metabolic rate (which in addition to maintenance costs includes varying and usually non-quantified amounts of routine activity, such as locomotion, specific dynamic action due to food digestion, etc.) or active metabolic rate may be different. In fact, if the energy demands for basal maintenance are very high, one would anticipate a decrease in other activities such as locomotion, reproduction, etc.; if these decreases balance the increase in standard metabolic rate, no change in the total $\dot{\mathrm{MO}}_{2}$ will be found, and, if the drop in these activities is larger, a decline in $\dot{M O}_{2}$ will be seen.

Overall, the routine metabolic rate is probably the least useful (and paradoxically most often measured) parameter for determining the effects of metal exposure on energy costs, because varying levels of routine activities will mask the effects of metal exposure, a fact demonstrated by the great variability of response to metals when routine $\dot{\mathrm{MO}}_{2}$ are measured (Table 4). In contrast, standard metabolic rates and active metabolic rates are easier to interpret from the viewpoint of physiology (reflecting basal maintenance costs and maximum aerobic capacity, respectively) and show a more consistent response to metal exposure (Table 4 and text below). The few currently available studies that have specifically measured standard metabolic rates (SMR) in response to metals in aquatic ectotherms support the hypothesis that exposure to sublethal metal concentrations result in elevated SMR (Table 4). Thus, SMR was considerably elevated in Cd-exposed eastern oysters (Cherkasov et al. 2006a, Lannig et al. 2006) and in Cd-exposed marine clams Ruditapes decussatus starved for 2 mo (Baghdiguian \& Riva 1985). Notably, $\mathrm{Cd}$ exposure also resulted in a stronger negative tissue growth in starved clams and inverted the order in which different energy reserves were used during starvation (Baghdiguian \& Riva 1985). In control animals, lipoprotein reserves were used first, followed by carbohydrates (after $1 \mathrm{mo}$ ) and proteins (after $2 \mathrm{mo}$ ), while, in Cd-exposed animals, carbohydrate reserves were used up first, followed by lipoproteins and lastly proteins (Baghdiguian \& Riva 1985). This order of use of energy reserves closely resembles that used during gonadal maturation and suggests that $\mathrm{Cd}$ exposure leads to an additional energy expenditure that requires reserves that can be rapidly mobilized, such as glycogen.

In contrast, the active metabolic rate (measured as the maximum sustainable $\dot{M O}_{2}$ ) decreased in steelhead trout Salmo gairdneri following $5 \mathrm{~d}$ of $\mathrm{Cu}$ exposure, implying problems with oxygen uptake and/or delivery during active locomotion (Waiwood \& Beamish 1978). Postexercise $\dot{M O}_{2}$ after swimming to exhaustion (which is a proxy for maximal sustainable $\mathrm{MO}_{2}$ ) decreased in yellow perch Perca flavescens from metal-contaminated lakes and was negatively related to $\mathrm{Cu}$ and $\mathrm{Cd}$ levels in the fish (Couture \& Kumar 2003). Aerobic swimming performance, as determined by the maximal swimming speed $\left(U_{\text {crit }}\right)$ and relative scope for activity, was also impaired in perch with high accumulated levels of $\mathrm{Cu}$ and $\mathrm{Cd}$ from polluted lakes (Rajotte \& Couture 2002, Couture \& Kumar 2003). Similarly, in Cu-exposed rainbow trout Oncorhyncus mykiss a strong reduction in swimming performance was observed, which progressed as the duration of $\mathrm{Cu}$ exposure increased (Clearwater et al. 2002). This indicates similarity of aerobic response to metals in laboratory and field exposures. A decrease in the active metabolic rate in metal-exposed ectotherms may reflect an impaired capacity for aerobic ATP production and systemic oxygen delivery (Byczkowski \& Sorenson 1984, Wallace \& Starkov 2000, Sokolova 2004, Ivanina et al. 2008b, Lannig et al. 2008) and/or an energetic trade-off due to the metal-induced increase of basal maintenance costs (Sibly \& Calow 1989, Calow \& Forbes 1998, Cherkasov et al. 2006a, Lannig et al. 2006) and, as a result, less energy available for sustained activity. Irrespective of the exact mechanisms, a decrease in active metabolic rate may negatively affect the organism's locomotion and have an impact on its ability to catch prey or avoid predators.

The above data show that the hypothesis that elevated energy demand for basal maintenance plays a key role in the interactive effects of temperature and metal stress is both theoretically plausible and experimentally supported by the available (albeit limited) data. Carefully designed studies are needed to extensively test this hypothesis. Several complementary 
approaches can be used to assess the metabolic costs of metal exposure and their interactions with elevated temperatures. Optimally, all components of energy budget (including standard metabolic rate, as well as scopes for growth, reproduction and activity) should be determined to identify the critical costs of metal and temperature stress. However, such an approach is time- and effort-consuming and may not be feasible for all organisms and practical applications. Alternatively, SMR can be determined in post-prandial resting animals with no locomotory activity; if metal detoxification and damage repair is associated with a significant energy cost, an increase in SMR is expected. Determination of metabolic rate with simultaneous quantification of the activity levels (i.e. using swimming tunnels or simultaneous $\mathrm{MO}_{2}$ measurements and video recording) can also provide important information of energy costs for metal and temperature stress by comparing whether slopes of $\dot{M O}_{2}$ on activity levels and/or maximal sustained $\dot{\mathrm{MO}}$ 2 and SMR (extrapolated as $\dot{\mathrm{MO}}$ 2 at zero activity) are affected by these 2 stressors. Determination of routine metabolic rates without the simultaneous quantification of activity levels cannot be recommended, because the interpretation of such data would be hindered by the impossibility to separate the potentially opposing effects of metal exposure and/or temperature on the basal maintenance costs and on the costs of active locomotion.

\subsection{Energy supply}

An elevated energy demand for basal metabolism appears to be a common mechanism of action for trace metals and elevated temperature stress, which may account for their synergistic effects on animal physiology and survival. However, elevated energy demand per se may not be a problem as long as it is met by a sufficient energy supply from food and/or body energy resources and as long as the systemic functions (ventilation and circulation) and cellular metabolic machinery can provide enough ATP to sustain elevated basal metabolism. The existing data, however, indicate that this is not the case. For example, in eastern oysters Crassostrea virginica, elevated temperature exaggerates the effects of a toxic metal $(\mathrm{Cd})$ by further increasing standard metabolic rate until, at a certain threshold of combined temperature and metal stress, no further increase in oxygen uptake is possible due to limitations of oxygen uptake systems (Lannig et al. 2006). As a result, blood oxygenation decreases in oysters exposed to $\mathrm{Cd}$ at $28^{\circ} \mathrm{C}$, but not at 20 or $24^{\circ} \mathrm{C}$ (Lannig et al. 2008). In oysters, circulatory system capacity, including heart rate and tissue hemolymph supply, was similar between control and Cd-exposed animals even at high temperatures (Lannig et al. 2008), in- dicating a depressed capacity for adjustments in circulatory performance to counteract the concomitant limitation of oxygen uptake in metal-exposed animals (Brown \& Newell 1972, Spicer \& Weber 1991, Nonnotte et al. 1993, Lawson et al. 1995, Hebel et al. 1997, Gregory et al. 1999, Leung et al. 2000). Indeed, high levels of trace metals often suppress ventilation and perfusion of respiratory organs in aquatic ectotherms, although relatively little is known about their effects at low sublethal concentrations. An important mechanism for such suppression involves damage to respiratory epithelia, impairing oxygen uptake and leading to hypoxemia. Thus, exposures to high levels of $\mathrm{Cd}, \mathrm{Cu}, \mathrm{Zn}$, or $\mathrm{Hg}$ result in degeneration of cilia, vacuolization, cellular hyperplasia and the appearance of necrotic cells in gills of marine mollusks and crustaceans (Brown \& Newell 1972, Spicer \& Weber 1991, Nonnotte et al. 1993, Lawson et al. 1995, Hebel et al. 1997, Gregory et al. 1999, Leung et al. 2000). Excessive mucus production is another common response to acute metal stress, limiting absorption of metals on the one hand, but interfering with $\mathrm{O}_{2}$ uptake on the other (Naimo et al. 1992, Sze \& Lee 1995, Leung et al. 2000). In some organisms (such as the crab Callinectes similis) exposure to $\mathrm{Cd}$ and $\mathrm{Cr}$ resulted in a reduction in the percentage of oxygen extraction (calculated as a ratio of $\dot{\mathrm{MO}}$ to the initial $\mathrm{O}_{2}$ concentration in respiration chambers), indicating a lower efficiency of $\mathrm{O}_{2}$ uptake at the respiratory surfaces (Ramirez et al. 1989). Similarly, exposure to 0.5 or $100 \mathrm{mg} \mathrm{l}^{-1} \mathrm{~Pb}$ resulted in a notable reduction of oxygen transfer across the gills in crayfish Cherax destructor (Ahern \& Morris 1999). Combination with elevated temperature would further exaggerate this hypoxemia due to the elevated oxygen demand on the one hand, and lower $\mathrm{O}_{2}$ solubility at high temperatures on the other.

The effects of trace metal exposure on the circulation system in aquatic ectotherms have not been extensively studied, and available data indicate variable responses. In oysters, heart rate was not affected by exposure to $\mathrm{Cd}$ in the environmentally relevant temperature range $\left(20\right.$ to $28^{\circ} \mathrm{C}$ ) (Lannig et al. 2008). In contrast, in the crab Carcinus maenas, acute exposure to high $\mathrm{Cu}$ levels resulted in a decrease of heart rate (Depledge 1984). In the marine gastropod Hemifusus tuba exposure to arsenic led to a strong decrease in heart rate at $30^{\circ} \mathrm{C}$, but no change at $23.5^{\circ} \mathrm{C}$ (Depledge \& Phillips 1987). Notably, arsenic exposure resulted in a lowered sensitivity to temperature in $H$. tuba $\left(Q_{10}\right.$ for heart rate was 1.51 in As-exposed snails vs. 2.08 in the controls), indicating that circulation may become limiting in metal-exposed animals at elevated temperatures (Depledge \& Phillips 1987).

Oxygen transport is another aspect of aerobic metabolism that can be impaired by metal exposure and elevated temperatures. In species that utilize hemocyanin 
or hemoglobin for oxygen transport, heavy metals can disrupt the respiratory functions of these pigments, negatively affecting the oxygen-carrying capacity of the blood. Thus, in dogwhelks Nucella lapillus, the $\mathrm{O}_{2}$-carrying capacity of hemolymph was significantly reduced by Cd exposure (Leung et al. 2000), and Cu exposure resulted in a decrease in hemocyanin concentration in the hemolymph of Carcinus maenas (Bjerregaard \& Vislie 1986). In the polychaete Arenicola marina, $\mathrm{Cu}$ and $\mathrm{Zn}$ exposure resulted in a decrease of oxygen affinity of their respiratory pigment erythrocruorin, and thus inhibition of $\mathrm{O}_{2}$ binding at the respiratory surface and $\mathrm{O}_{2}$ delivery to metabolizing tissues (Everaarts et al. 1979, Everaarts 1986). Similarly, Cd exposure led to a decrease in oxygen affinity of erythrocruorin in A. marina, although this effect was only evident in vivo and not in vitro (Everaarts \& Reichert 1988). Cd exposure also considerably increased the apparent heat of oxygenation of erythrocruorin, which would diminish the adaptational capacity of the respiratory function of $A$. marina toward temperature changes in its natural habitat (Everaarts \& Reichert 1988). In arcid bivalves Scapharca inaequivalvis, blood oxygen transport mediated by hemoglobin-containing erythrocytes is also impaired by Cd exposure, although in this case the mechanism involves a decrease in hematocrit and hemocyte count, and not in oxygen affinity (Weber et al. 1990). Given that the oxygen affinity of respiratory pigments, including hemoglobins and hemocyanins, tends to decrease with increasing temperatures (Burnett 1992, Weber \& Vinogradov 2001, Decker et al. 2007), the combined action of trace metals, high temperature and low oxygen solubility in the water may strongly limit oxygen uptake and delivery in the respiratory organs of aquatic ectotherms.

Temperature and metal exposure can also synergistically affect energy supply at the cellular ATP production sites. Trace metals strongly affect mitochondrial function by reducing activity of the electron transport chain and ATP production, decreasing mitochondrial efficiency, elevating mitochondrial reactive oxygen species (ROS) production and/or increasing mitochondrial maintenance costs through elevated proton leak (Wallace \& Starkov 2000, Sokolova 2004, Cherkasov et al. 2006b and references therein). Studies in our laboratory have shown that elevated temperatures strongly increase the sensitivity of mitochondria to toxic metals. Thus, apparent inhibition constants for $\mathrm{Cd}$ (reflecting Cd concentrations required to inhibit $50 \%$ of respiration) were reduced by nearly 2 orders of magnitude by a temperature increase from 15 to $35^{\circ} \mathrm{C}$ in oyster mitochondria: from 80 to $3 \mu \mathrm{M}$ for ADP-stimulated State 3 respiration and from 172 to $2 \mu \mathrm{M}$ for resting (State 4 ) respiration, respectively (Sokolova 2004). Moreover, exposure to $\mathrm{Cd}$ resulted in a significant decrease in mitochondrial abun- dance in gill and hepatopancreas (digestive gland) of oysters, with a notably stronger reduction at $28^{\circ} \mathrm{C}$ than at 20 or $12^{\circ} \mathrm{C}$ (Cherkasov et al. 2006a). Elevated temperatures also exaggerated the $\mathrm{Cd}$-induced inactivation of the key mitochondrial enzyme aconitase (Cherkasov et al. 2006b) and inhibition of electron transport complexes and Krebs cycle enzymes in oyster mitochondria (Ivanina et al. 2008b). Activation energy of several key mitochondrial enzymes was also significantly reduced by $\mathrm{Cd}$ exposure, suggesting that their ability to adequately respond to changes in environmental temperature is impaired (Ivanina et al. 2008b). This implies that aerobic capacity can be strongly impaired by the combined action of elevated temperature and trace metals in ectotherms, resulting in an energy deficiency even when the systemic oxygen supply is unaffected.

Last but not least, both high temperature and metal exposure can result in oxidative stress due to the excessive ROS production in mitochondria, inhibition of cellular antioxidant defense, or both. Oxidative stress, in turn, results in damage to the vital cellular components, including membranes, proteins and DNA, and eventually leads to cell death. The effects of temperature and trace metals as single stressors on oxidative stress have been extensively studied, and there are several excellent reviews dealing with these issues, to which we refer the interested reader (Valko et al. 2005, Abele et al. 2007 and references therein). In contrast, very few studies have addressed the combined effects of these 2 stressors on oxidative stress, and the mechanisms and physiological consequences of their interaction on ROS production and antioxidant defense is poorly understood. Studies in our laboratory have shown that exposure to $\mathrm{Cd}$ results in oxidative damage of oyster tissues at $28^{\circ} \mathrm{C}$, but not at 20 or $24^{\circ} \mathrm{C}$, as indicated by accumulation of malondialdehyde, an end product of lipid peroxidation (Lannig et al. 2006). This suggests that at elevated temperatures, tissue antioxidant defenses are overwhelmed by excessive Cd-induced ROS production, and oxidative damage ensues. This view is further supported by the fact that ROS-mediated inactivation of mitochondrial aconitase in oyster mitochondria was significant at $30^{\circ} \mathrm{C}$, but not at $20^{\circ} \mathrm{C}$ (Cherkasov et al. 2006b). Further studies are needed to determine whether temperature-metal synergy on ROS production is a general phenomenon in aquatic ectotherms, and what implications this has for whole-organism physiology and survival.

\section{EFFECTS OF METALS ON THERMAL TOLERANCE}

The interactive effects of elevated temperature and trace metal exposure have 2 consequences in aquatic 
ectotherms: (1) the above-described sensitization of an organism to metal toxicity and (2) a decrease in thermal tolerance limits in metal-exposed animals. These consequences are, in fact, 2 sides of the same coin and are tightly linked with the synergistic effects of temperature and metal stress on aerobic metabolism.

According to the concept of oxygen-limited thermal tolerance in aquatic ectotherms (Pörtner 2001), the temperature range in which an animal exhibits highest capacity for growth and reproduction is determined by its optimized oxygen supply. Upper and lower limits of thermal tolerance are set by limitations in aerobic scope, due to the onset of a mismatch between oxygen supply and demand and a reduced capacity to deliver oxygen to the tissues/organs (see Frederich \& Pörtner 2000, Mark et al. 2002, Wilson et al. 2002, Sartoris et al. 2003, Lannig et al. 2004, 2008, Pörtner et al. 2006 and references therein). This limitation in aerobic scope arises before thermal stress causes a transition to anaerobic metabolism and further effects at cellular and biochemical levels when critical temperatures are reached (Pörtner 2002, Pörtner \& Knust 2007). In addition to impaired circulatory and ventilatory performance, other factors such as mitochondrial functioning and oxygen-carrying capacities by respiratory pigments contribute to thermally induced limitation of oxygen (Melzner et al. 2007). The width of the window of thermal tolerance may vary greatly between species and environments and is typically narrow in stenothermal species from permanently cold environments (e.g. deep sea and polar regions) and the tropics, and considerably wider in eurythermal temperate species, especially those from habitats with wide temperature fluctuations, such as intertidal zones and shallow waters (Somero \& de Vries 1967, Pörtner et al. 1999, 2001, 2007, Sommer \& Pörtner 2002, Peck et al. 2004, Somero 2005, Compton et al. 2007).

The above-described effects of metal exposure on metabolism and the observed relationship between temperature tolerance and aerobic metabolism tally well with the following assumption: metal exposure will interfere with thermal tolerance, resulting in decreased temperature limits in metal-exposed animals (Fig. 3), especially in light of recent findings that show that exposure to toxic metals results in hypoxemia in aquatic ectotherms (e.g. in the carp Cyprinus carpio exposure to $\mathrm{Cd}$ led to the onset of partial anaerobiosis, as indicated by the upregulation of lactate dehydrogenase activity and significant accumulation of the anaerobic metabolites pyruvate and lactate; Suresh et al. 1993). Notably, transition to partial anaerobiosis was detected at both low (sublethal) and lethal Cd levels, although putative mechanisms for this transition were different: at lethal Cd levels it was associated with inhibition of aerobic respiration due to gill

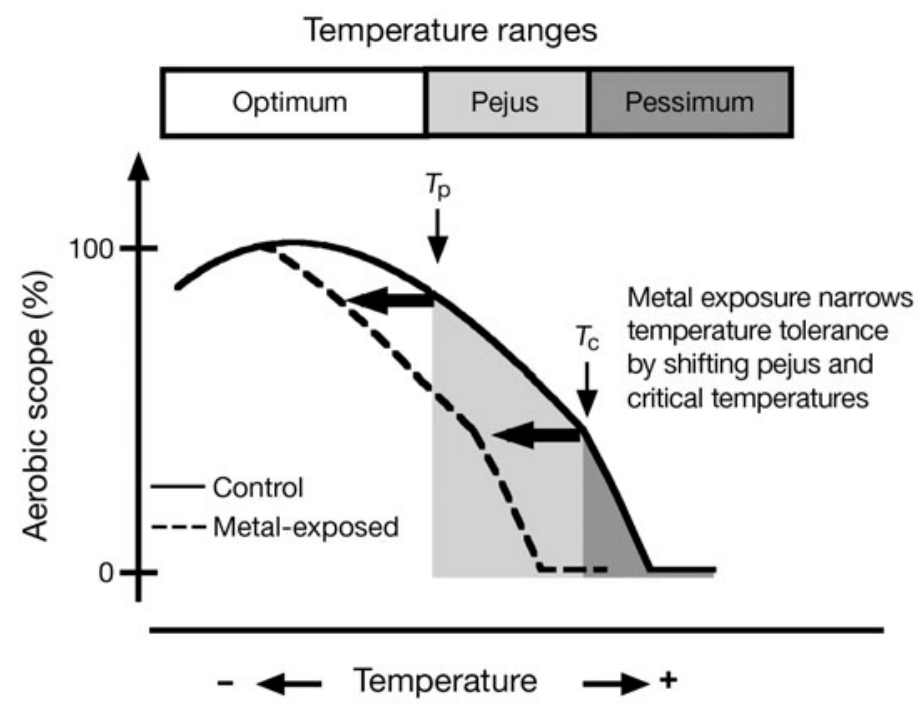

Fig. 3. Effects of metal exposure on thermal tolerance of aquatic ectotherms. Interpretation of pollution effects on thermal tolerance limits in the framework of the conceptual model of oxygen-limited thermal tolerance in water-breathing animals (modified after Frederich \& Pörtner 2000, see also Pörtner 2001). Following Shelford's law of tolerance, the concept defines the temperature tolerance thresholds pejus $\left(T_{\mathrm{p}}\right)$ and critical $\left(T_{\mathrm{c}}\right)$ temperatures. The pejus range is characterized by a declining aerobic scope and extends until anaerobic metabolism finally sets in $\left(T_{\mathrm{c}}\right)$ caused by temperature-induced reduction in aerobic scope due to a mismatch between oxygen demand and supply capacities (see Section 4). Metal exposure impairs aerobic capacities, causing a downward shift of

$T_{\mathrm{p}}$ and $T_{\mathrm{c}}$ temperatures as indicated by the bold arrows

damage, whereas at sublethal Cd exposures anaerobic metabolism occurred hand-in-hand with high aerobic oxidation and probably reflected limitation of aerobic metabolism and its failure to fully cover elevated energy demand due to cellular detoxification and repair (Suresh et al. 1993). A similar situation was observed in crabs Scylla serrata during $\mathrm{Cd}$ exposure, which resulted in impaired mitochondrial enzyme capacities and the onset of partial anaerobiosis with induction of glucose-6-phosphate dehydrogenase and lactate accumulation (Reddy \& Bhagyalakshmi 1994). A compensatory increase in tissue anaerobic capacities that went hand-in-hand with a decrease in aerobic scope was also found in metal-contaminated yellow perch Perca flavescens and Mozambique tilapia Oreochromis mossambicus (James et al. 1992, Couture \& Kumar 2003, Couture \& Rajotte 2003). This implies that metal stress combined with elevated temperatures will result in a rapid onset of tissue hypoxemia and aerobic energy deficiency, shifting pejus and critical temperatures to the lower values (Fig. 3).

Although the effects of metal exposure on critical and pejus temperatures have not been specifically studied, several studies provide evidence that expo- 
sure to metals can indeed affect thermal tolerance of aquatic ectotherms. Thus, the critical thermal maximum $\left(\mathrm{CT}_{\text {maxi }}\right.$ determined as the temperature at which coordinated locomotion of an organism is disrupted, indicating neural dysfunction) was reduced by exposure to $\mathrm{Cd}$ or $\mathrm{Cr}$ in the marine prawn Macrobrachium rosenbergii and in the stonefly nymph Clioperla clio (Poulton et al. 1989, Rosas \& Ramirez 1993). The decrease in $\mathrm{CT}_{\max }$ was accompanied by a decrease in tissue $\mathrm{O}_{2}$ concentrations in the prawn, indicating that disruption of energy metabolism was involved (Rosas \& Ramirez 1993). In coho salmon Oncorhynchus kisutch and steelhead trout Salmo gairdneri exposure to $\mathrm{Ni}$ also led to a reduction in $\mathrm{CT}_{\max }$ and the upper lethal temperature limit, and $\mathrm{CT}_{\max }$ values of Ni-exposed fish were also more heterogeneous than in the controls (Becker \& Wolford 1980). A similar decrease in $\mathrm{CT}_{\max }$ was found in muskellunge fry Esox masquinongy exposed to sublethal concentrations of arsenic (Paladino $\&$ Spotila 1978). In contrast, Cd exposure of green sunfish Lepomis cyanellus had no effect on $\mathrm{CT}_{\max }$, perhaps due to the fact that the green sunfish is a very hardy eurythermal species with a high thermal tolerance (Carrier \& Beitinger 1988).

In active organisms such as fishes, metal exposure can lead to behavioral selection of a lower preferred temperature (if given a choice) (Gordon 2005). Thus, $\mathrm{Cd}$ and $\mathrm{Cu}$ exposure resulted in a decrease in the selected water temperature in Atlantic salmon Salmo salar, whereas Zn had no effect (Peterson 1976, cited according to Gordon 2005). Interestingly, respiratory poisons and metabolic uncouplers have the same effect on preferred temperatures, suggesting that interference with aerobic metabolism underlies these effects. Thus, the mitochondrial uncoupler pentachlorophenol and an inhibitor of cytochrome $c$ oxidase, potassium cyanide, decreased preferred temperature in $S$. salar, although 2,4-dinitrophenol had no effect on preferred temperature, despite uncoupling of mitochondria (Javaid 1972, Peterson 1976). In the toad Buffo marinus, injections of sodium azide or cyanide also led to a behavioral selection of a lower preferred temperature (Branco \& Malvin 1996), as did exposure of protozoans Paramecium caudatum to sodium azide, cyanide, or 2,4-dinitrophenol (Malvin et al. 1994, Malvin 1998).

As a corollary, heavy metal exposure will have deleterious effects on the metabolic physiology of ectotherms, limit- ing their tolerance to elevated temperatures (e.g. during seasonal warming or global climate change). Here, we propose a conceptual model (Fig. 4) that integrates different aspects of metal toxicity under the umbrella of energy metabolism and bioenergetics; according to this model, metal exposure interferes with cellular processes such as ion homeostasis, protein stability and mitochondrial efficiency, leading to elevated costs for maintenance and detoxification (Fig. 4). Moreover, metal-induced effects on mitochondrial capacities and damage of gill structure and/or cardiac function impair oxygen supply systems. These opposing effects are generally balanced at moderate temperatures so that detoxification and repair capacities are sufficiently high to minimize the negative effect of metal exposure on oxygen supply systems (depending on metal concentration), and vice versa the oxygen supply is sufficiently high to cover elevated maintenance costs. The metabolic effects of metals become critical once an organism is in its thermal pejus range, where the aerobic scope is limited. With rising temperature, the synergistic effects of elevated temperature and metal exposure on energy demand for basal maintenance, detoxification and damage repair override the aerobic

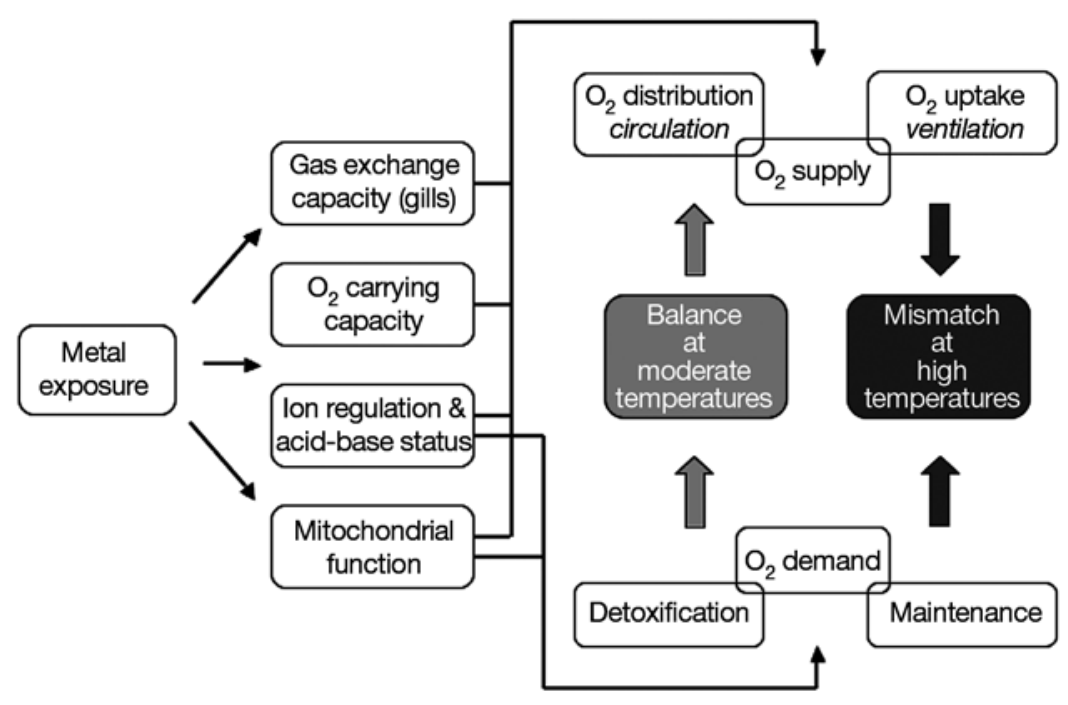

Fig. 4. Generalized physiological model of interactive effects of temperature and trace metals on aquatic ectotherms. Metal exposure interferes with several physiological and biochemical processes that affect aerobic metabolic capacities. At moderate temperatures, the metal-induced rise in oxygen demand can be balanced by a corresponding rise in oxygen supply. At elevated temperatures these effects become detrimental, resulting in a mismatch between oxygen demand and supply mainly due to impaired ventilatory performance (see Sections 3.2 and 4 for details). This model does not cover cases of metabolic rate depression, where acclimation/adaptation to metal exposure occurs by decreasing the rates of metabolic processes and entering a metabolically depressed or dormant state with a concomitant decrease in energy demand and supply. According to the available literature, such situations are rare in metal- and temperature-stressed ectotherms 
metabolic machinery, resulting in progressive hypoxemia. As a result of the mismatch between elevated energy demand and limited energy supply during exposures to elevated temperatures and metal, energydependent cellular protective mechanisms involved in detoxification and damage repair (e.g. metallothioneins and HSPs) are more likely to fail, leading to elevated mortality and whole-organism physiological stress (Lannig et al. 2006, 2008).

\section{SUMMARY AND FUTURE DIRECTIONS}

Interactions between environmental temperature and metal pollution strongly affect physiological tolerance to both stressors and can limit the survival and distribution of ectotherm populations in the face of global climate change and increasing anthropogenic pollution of aquatic environments. Interference with aerobic metabolism, including energy demand, oxygen supply and mitochondrial function, forms a physiological basis for these interactions. Both elevated temperature and toxic metal stress can, independently of each other, result in elevated maintenance costs, reduce mitochondrial efficiency and impair oxygen uptake and delivery to the tissues, leading to hypoxemia and energy deficiency. As a result, exposure to one of these stressors sensitizes an organism to the other. This finding may have broader implications and holds true not only for trace metals, but also for other pollutants and environmental stressors that require an elevated energy demand for stress or negatively affect energy supply or both, such as hypoxia, metabolic toxin, antiparasite and other immune defense mechanisms (Malvin et al. 1994, Branco \& Malvin 1996, Stefaniak et al. 2005, Flye-Sante-Marie et al. 2007). In the future, detailed studies focusing on energy budget as a key target for multiple stressors will be needed to extensively test this bioenergetic hypothesis of severe temperature-pollutant interactions on aerobic energy metabolism of marine ectotherms and to extend it to other pollutants and natural stressors. Currently, very little is known about the effects of multiple stressors, such as salinity, hypoxia, food availability or - against the background of climate change-such as ocean acidification and increased $\mathrm{CO}_{2}$ levels, on the sensitivity to temperature and metals; however, recent studies indicate that multiple stressors in the field may increase sensitivity to metals in aquatic ectotherms when compared to laboratory exposures at the same temperatures and metal concentrations (Witeska \& Jezierska 2003, Gauthier et al. 2006). Another important, but currently understudied, aspect of temperature-pollution interaction is an understanding of the effects of fluctuating (as opposed to constantly ele- vated) temperatures or long-term temperature acclimation/adaptation, which may affect organisms differently than acute temperature change (Spurgeon et al. 2005). Using these studies, quantitative toxicokinetic and physiological models of temperature-pollution interactions can be developed that will assist in predicting the effects of pollutants on ectotherm populations in the face of global climate change. Physiological studies of temperature-pollution interactions at all levels of biological organization (from molecular/cellular to whole organism and populations) would be crucial for generalizations and predictions of the effects of stressors within and across species. Since the relationships become more and more complicated as the number of variables increases, computer models will be critical for fully exploring these relationships. Such models will become indispensable for predicting the effects of multiple stressors on ectotherm populations facing global climate changes and determining safety margins in ecological risk assessments, and physiological studies will play a key part in such models by providing realistic input values for model parameters.

Acknowledgements. During this work I.M.S. was supported by funds provided through a National Science Foundation CAREER award (IBN-0347238) and the University of North Carolina at Charlotte.

\section{LITERATURE CITED}

Abdullah AM, Ireland MP (1986) Seasonal studies on Cd concentration and toxicity, oxygen consumption, digestive gland glycogen, and lipid in dog whelks collected at Aberystwyth, Wales. Mar Pollut Bull 17:562-566

Abele D, Philip E, Gonzalez PM, Puntarulo S (2007) Marine invertebrate mitochondria and oxidative stress. Front Biosci 12:933-946

Adams SM (2005) Assessing cause and effect of multiple stressors on marine systems. Mar Pollut Bull 51:649-657

Ahern MD, Morris S (1999) Respiratory, acid-base, and metabolic responses of the freshwater crayfish Cherax destructor to lead contamination. Comp Biochem Physiol A 124: 105-111

Amiard JC, Amiard-Triquet C, Barka S, Pellerin J, Rainbow PS (2006) Metallothioneins in aquatic invertebrates: their role in metal detoxification and their use as biomarkers. Aquat Toxicol 76:160-202

Atwell L, Hobson KA, Welch HE (1998) Biomagnification and bioaccumulation of mercury in an arctic marine food web: insights from stable nitrogen isotope analysis. Can J Fish Aquat Sci 55:1114-1121

Austin GE, Rehfish MM (2005) Shifting distributions of migratory fauna in relation to climatic change. Glob Change Biol 11:31-38

> Baghdiguian S, Riva A (1985) Metabolic modifications brought by the synergic action of cadmium and experimental starvation of clams Ruditapes decussatus. Mar Environ Res 17:289

Baines SB, Fisher NS, Kinney EL (2005) Influence of temperature on dietary metal uptake in Arctic and temperate mussels. Mar Ecol Prog Ser 289:201-213 
Baines SB, Fisher NS, Kinney EL (2006) Effects of temperature on the uptake of aqueous metals by blue mussels Mytilus edulis from Arctic and temperate waters. Mar Ecol Prog Ser 308:117-128

Balamurugan K, Schaffner W (2006) Copper homeostasis in eukaryotes: teetering on a tightrope. Biochim Biophys Acta 1763:737-746

Barber I, Baird DJ, Calow P (1990) General responses of Daphnia magna Straus to toxic stress. II. Physiological effects. Funct Ecol 4:409-414

Bargagli R (2000) Trace metals in Antarctica related to climate change and increasing human impact. Rev Environ Contam Toxicol 166:129-173

Bat L, Akbulut M, Culha M, Gündogdu A, Satilmis HH (2000) Effect of temperature on the toxicity of zinc, copper and lead to the freshwater amphipod Gammarus pulex pulex (L., 1758). Turk J Zool 24:409-415

Bauman JW, Liu J, Klaassen CD (1993) Production of metallothionein and heat shock proteins in response to metals. Fundam Appl Toxicol 21:15-22

Beaugrand G (2004) The North Sea regime shift: evidence, causes, mechanisms and consequences. Prog Oceanogr 60:245-262

Becker CD, Wolford MG (1980) Thermal resistance of juvenile salmonids sublethally exposed to nickel, determined by the critical thermal maximum method. Environ Pollut 21:181-189

Begon M, Townsend CR, Harper JL (2006) Ecology: from individuals to ecosystems, 4th edn. Blackwell Publishing, Malden, MA

Bervoets L, Blust R (1999) Bioavailability of cadmium and zinc to midge larvae under natural and experimental conditions: effects of some environmental factors. Belg J Zool 129:269-284

Bervoets L, Blust R, Verheyen R (1996) Effect of temperature on cadmium and zinc uptake by the midge larvae Chironomus riparius. Arch Environ Contam Toxicol 31: 502-511

Bjerregaard P, Vislie T (1986) Effect of copper on ion- and osmoregulation in the shore crab Carcinus maenas. Mar Biol 91:69-76

Boeckman CJ, Bidwell JR (2006) The effects of temperature, suspended solids, and organic carbon on copper toxicity to two aquatic invertebrates. Water Air Soil Pollut 171: 185-202

Branco LG, Malvin GM (1996) Thermoregulatory effects of cyanide and azide in the toad, Bufo marinus. Am J Physiol 270:R169-R173

Brown BE, Newell RC (1972) The effect of copper and zinc on the metabolism of the mussel Mytilus edulis. Mar Biol 16: 108-111

Burnett LE (1992) Integrated function of the respiratory pigment hemocyanin in crabs. Am Zool 32:438-446

Byczkowski JZ, Sorenson JRJ (1984) Effects of metal compounds on mitochondrial function: a review. Sci Total Environ 37:133-162

> Cairns J Jr, Heath AG, Parker BC (1975) The effects of temperature upon the toxicity of chemicals to aquatic organisms. Hydrobiologia 47:135-171

Calow P, Forbes VE (1998) How do physiological responses to stress translate into ecological and evolutionary processes? Comp Biochem Physiol 120A:11-16

Campbell LM, Norstrom RJ, Hobson KA, Muir DCG, Backus S, Fisk AT (2005) Mercury and other trace elements in a pelagic Arctic marine food web (Northwater Polynya, Baffin Bay). Sci Total Environ 351-352:247-263

Carrier R, Beitinger TL (1988) Resistance of temperature tol- erance ability of green sunfish to cadmium exposure. Bull Environ Contam Toxicol 40:475-480

Cattani O, Serra R, Isani G, Raggi G, Cortesi P, Carpene E (1996) Correlation between metallothionein and energy metabolism in sea bass Dicentrarchus labrax, exposed to cadmium. Comp Biochem Physiol 113C:193-199

Cherkasov AS, Biswas PK, Ridings DM, Ringwood $\mathrm{AH}$, Sokolova IM (2006a) Effects of acclimation temperature and cadmium exposure on cellular energy budgets in the marine mollusk Crassostrea virginica: linking cellular and mitochondrial responses. J Exp Biol 209:1274-1284

Cherkasov AS, Ringwood AH, Sokolova IM (2006b) Combined effects of temperature acclimation and cadmium exposure on mitochondrial function in eastern oysters Crassostrea virginica Gmelin (Bivalvia: Ostreidae). Environ Toxicol Chem 25:2461-2469

Cherkasov AS, Grewal S, Sokolova IM (2007) Combined effects of temperature and cadmium exposure on haemocyte apoptosis and cadmium accumulation in the eastern oyster Crassostrea virginica (Gmelin). J Therm Biol 32: 162-170

Cheung SG, Wong LS (1998) Physiological responses of the subtidal prosobranch, Babylonia lutosa (Gastropoda: Buccinidae), to copper. Sci Total Environ 214:185-191

Clark RB (2001) Marine pollution, 5th edn. Oxford University Press, Oxford

Clearwater SJ, Farag AM, Meyer JS (2002) Bioavailability and toxicity of dietborne copper and zinc to fish. Comp Biochem Physiol C 132:269-313

- Compton TJ, Rijkenberg MJA, Drent J, Piersma T (2007) Thermal tolerance ranges and climate variability: a comparison between bivalves from differing climates. J Exp Mar Biol Ecol 352:200-211

Cooper CA, Handy RD, Bury NR (2006) The effects of dietary iron concentration on gastrointestinal and branchial assimilation of both iron and cadmium in zebrafish (Danio rerio). Aquat Toxicol 79:167-175

> Couture P, Kumar PR (2003) Impairment of metabolic capacities in copper and cadmium contaminated wild yellow perch (Perca flavescens). Aquat Toxicol 64:107-120

> Couture P, Rajotte JW (2003) Morphometric and metabolic indicators of metal stress in wild yellow perch (Perca flavescens) from Sudbury, Ontario: a review. J Environ Monit 5:216-221

- Coyle P, Philcox JC, Carey LC, Rofe AM (2002) Metallothionein: the multipurpose protein. Cell Mol Life Sci 59: 627-647

Crockett EL (1998) Cholesterol function in plasma membranes from ectotherms: membrane-specific roles in adaptation to temperature. Am Zool 38:291-304

Croteau MN, Luoma SN, Pellet B (2007) Determining metal assimilation efficiency in aquatic invertebrates using enriched stable metal isotope tracers. Aquat Toxicol 83: 116-125

> Decker H, Hellmann N, Jaenicke E, Lieb B, Meissner U, Markl J (2007) Minireview: recent progress in hemocyanin research. Integr Comp Biol 47:631-644

De Mora S, Fowler SW, Wyse E, Azemard S (2004) Distribution of heavy metals in marine bivalves, fish and coastal sediments in the Gulf and Gulf of Oman. Mar Pollut Bull 49:410-424

Denton GRW, Burdon-Jones C (1981) Influence of temperature and salinity on the uptake, distribution and depuration of mercury, cadmium and lead by the blacklip oyster Saccostrea echinata. Mar Biol 64:317-326

$>$ Depledge $\mathrm{MH}$ (1984) Disruption of circulatory and respiratory activity in shore crabs (Carcinus maenas [L.]) exposed 
to heavy metal pollution. Comp Biochem Physiol C 78: 445-459

Depledge MH, Phillips DJH (1987) Arsenic uncoupled cardiac and respiratory responses of Hemifusus tuba (Gmelin) to thermal stress. Asian Mar Biol 4:91-96

Douben PET (1989) Uptake and elimination of waterborne cadmium by the fish Noemacheilus barbatulus L. (stone loach). Arch Environ Contam Toxicol 18:576-586

Everaarts JM (1986) Is monitoring of respiratory properties of the haemoglobin of the lugworm Arenicola marina meaningful? Environ Monit Assess 7:273-283

Everaarts JM, Reichert MJM (1988) The effect of cadmium on some oxygen-binding properties of the blood pigment of the lugworm Arenicola marina (Annelida, Polychaeta). Mar Environ Res 25:275-289

> Everaarts JM, Osborne WK, Verhaaf E (1979) Effect of copper and zinc on some oxygen binding properties of the haemoglobin of the polychaete Arenicola marina. Neth J Sea Res 13:571-580

Farkas T, Fodor E, Kitajka K, Halver JE (2001) Response of fish membranes to environmental temperature. Aquac Res 32:645-655

Feder ME, Hofmann GE (1999) Heat-shock proteins, molecular chaperones, and the stress response: evolutionary and ecological physiology. Annu Rev Physiol 61:243-282

Felts PA, Heath AG (1984) Interactions of temperature and sublethal environmental copper exposure on the energy metabolism of bluegill, Lepomis macrochirus Rafinesque. J Fish Biol 25:445-453

Fischer H (1986) Influence of temperature, salinity, and oxygen on the cadmium balance of mussels Mytilus edulis. Mar Ecol Prog Ser 32:265-278

Fischlin A, Midgley GF, Price JT, Leemans R and others (2007) Ecosystems, their properties, goods, and services. In: Parry ML, Canziani OF, Palutikof JP, van der Linden PJ, Hanson CE (eds) Climate change 2007: impacts, adaptation and vulnerability. Contribution of Working Group II to the 4th assessment report of the Intergovernmental Panel on Climate Change. Cambridge University Press, Cambridge, p 211-272

Fisk AT, de Wit CA, Wayland M, Kuzyk ZZ and others (2005) An assessment of the toxicological significance of anthropogenic contaminants in Canadian arctic wildlife. Sci Total Environ 351/352:57-93

Flye-Sante-Marie J, Pouvreau S, Paillard C, Jean F (2007) Impact of Brown Ring Disease on the energy budget of the Manila clam Ruditapes philippinarum. J Exp Mar Biol Ecol 349:378-389

Frederich M, Pörtner HO (2000) Oxygen limitation of thermal tolerance defined by cardiac and ventilatory performance in the spider crab, Maja squinado (Decapoda). Am J Physiol 279:R1531-R1538

> Gauthier C, Couture P, Pyle GG (2006) Metal effects on fathead minnows (Pimephales promelas) under field and laboratory conditions. Ecotoxicol Environ Saf 63:353-364

Gómez JJ, Goy A, Canales ML (2008) Seawater temperature and carbon isotope variations in belemnites linked to mass extinction during the Toarcian (Early Jurassic) in central and northern Spain. Comparison with other European sections. Palaeogeogr Palaeoclimatol Palaeoecol 258:28-58

Gordon CJ (2005) Temperature and toxicology: an integrative, comparative and environmental approach. Taylor \& Francis, Boca Raton, FL

Gregory MA, George RC, Marshall DJ, Anandraj A, McClurg TP (1999) The effects of mercury exposure on the surface morphology of gill filaments in Perna perna. Mar Pollut Bull 39:116-121
Gupta PK, Khangarot BS, Durve VS (1981) The temperature dependence of the acute toxicity of copper to a freshwater pond snail, Viviparus bengalensis L. Hydrobiology 83: 461-464

Hall JM, Parrish CC, Thompson RJ (2002) Eicosapentaenoic acid regulates scallop (Placopecten magellanicus) membrane fluidity in response to cold. Biol Bull 202:201-203

Hand SC, Hardewig I (1996) Downregulation of cellular metabolism during environmental stress: mechanisms and implications. Annu Rev Physiol 58:539-563

> Hassler CS, Slaveykova VI, Wilkinson KJ (2004) Some fundamental (and often overlooked) considerations underlying the free ion activity and biotic ligand models. Environ Toxicol Chem 23:283-291

> Hazel JR (1995) Thermal adaptation in biological membranes: Is homeoviscous adaptation the explanation? Annu Rev Physiol 57:19-42

> Hebel DK, Jones MB, Depledge MH (1997) Responses of crustaceans to contaminant exposure: a holistic approach. Estuar Coast Shelf Sci 44:177-184

> Helmuth B, Harley CDG, Halpin PM, O'Donnell M, Hofmann GE, Blanchette CA (2002) Climate change and latitudinal patterns of intertidal thermal stress. Science 298: 1015-1017

Heugens EHW, Hendriks AJ, Dekker T, van Straalen NM, Admiraal W (2002) A review of the effects of multiple stressors on aquatic organisms and analysis of uncertainty factors for use in risk assessment. Crit Rev Toxicol 31(3): $247-284$

> Heugens EH, Jager T, Creyghton R, Kraak MH, Hendriks AJ, van Straalen NM, Admiraal W (2003) Temperaturedependent effects of cadmium on Daphnia magna: accumulation versus sensitivity. Environ Sci Technol 37:2145-2151

Hochachka PW, Somero GN (2002) Biochemical adaptation: mechanism and process in physiological evolution. Oxford University Press, Oxford

> Hoegh-Guldberg O (1999) Climate change, coral bleaching and the future of the world's coral reefs. Mar Freshw Res 50:839-866

> Hutcheson MS (1974) The effect of temperature and salinity on cadmium uptake by the blue crab Callinectes sapidus. Chesapeake Sci 15:237-241

> Hutchins DA, Teyssié JL, Boisson F, Fowler SW, Fisher NS (1996) Temperature effects on uptake and retention of contaminant radionuclides and trace metals by the brittle star Ophiothrix fragilis. Mar Environ Res 41:363-378

Hutchins DA, Stupakoff I, Hook S, Luoma SN, Fisher NS (1998). Effects of arctic temperature on distribution and retention of the nuclear waste radionuclides ${ }^{241} \mathrm{AM},{ }^{57} \mathrm{Co}$, and ${ }^{137} \mathrm{Cs}$ in the bioindicator bivalve Macoma balthica. Mar Environ Res 45:17-28

$>$ Hyun S, Lee T, Lee CH, Park YH (2006) The effects of metal distribution and anthropogenic effluents on the benthic environment of Gwangyang Bay, Korea. Mar Pollut Bull 52:113-120

Inza B, Ribeyre F, Boudou A (1998) Dynamics of cadmium and mercury compounds (inorganic mercury or methylmercury): uptake and depuration in Corbicula fluminea. Effects of temperature and pH. Aquat Toxicol 43:273-285

IPCC (Intergovernmental Panel on Climate Change) (2007) Fourth assessment report. Cambridge University Press, New York

- Ivanina AV, Sokolova IM (2008) Effects of cadmium exposure on expression and activity of P-glycoprotein in eastern oysters, Crassostrea virginica Gmelin. Aquat Toxicol 88:19-28

> Ivanina AV, Cherkasov AS, Sokolova IM (2008a) Effects of cadmium on cellular protein and glutathione synthesis 
and expression of stress proteins in eastern oysters, Crassostrea virginica Gmelin. J Exp Biol 211:577-586

Ivanina AV, Habinck E, Sokolova I (2008b) Differential sensitivity to cadmium of key mitochondrial enzymes in the eastern oyster, Crassostrea virginica Gmelin (Bivalvia: Ostreidae). Comp Biochem Physiol C 148:72-79

> James R, Sampath K, Punithavathi Ponmani K (1992) Effect of metal mixtures on activity of two respiratory enzymes and their recovery in Oreochromis mossambicus (Peters). Indian J Exp Biol 30:496-499

Javaid MY (1972) The course of selected temperature during thermal acclimation of some salmonids. Nucleus 9:103-106

Kambe T, Yamaguchi-Iwai Y, Sasaki R, Nagao M (2004) Overview of mammalian zinc transporters. Cell Mol Life Sci 61:49-68

Khan MAQ, Ahmed SA, Catalin BKA, Ajayi O (2006) Effect of temperature on heavy metal toxicity to juvenile crayfish, Orconectes immunis (Hagen). Environ Toxicol 21:513-520

Kultz D (2003) Evolution of the cellular stress proteome: from monophyletic origin to ubiquitous function. J Exp Biol 206:3119-3124

Kwok KWH, Leung KMY (2005) Toxicity of antifouling biocides to the intertidal harpacticoid copepod Tigriopus japonicus (Crustacea, Copepoda): effects of temperature and salinity. Mar Pollut Bull 51:830-837

La Sorte FA, Thompson FR (2007) Poleward shifts in winter ranges of North American birds. Ecology 88:1803-1812

Landis WG, Yu MH (2003) Introduction to environmental toxicology. Lewis Publishers, Boca Raton, FL

> Lanks KW (1983) Metabolite regulation of heat shock protein levels. Proc Natl Acad Sci USA 80:5325-5329

Lannig G, Bock C, Sartoris FJ, Pörtner HO (2004) Oxygen limitation of thermal tolerance in cod, Gadus morhua L. studied by magnetic resonance imaging and on-line venous oxygen monitoring. Am J Physiol 287:R902-R910

Lannig G, Flores JF, Sokolova IM (2006) Temperaturedependent stress response in oysters, Crassostrea virginica: pollution reduces temperature tolerance in oysters. Aquat Toxicol 79:278-287

Lannig G, Cherkasov AS, Pörtner HO, Bock C, Sokolova IM (2008) Cadmium-dependent oxygen limitation affects temperature tolerance in eastern oysters (Crassostrea virginica Gmelin). Am J Physiol 294:R1338-R1346

Lau S, Mohammed M, Tan Chi Yen A, Su`ut S (1998) Accumulation of heavy metals in freshwater mollusks. Sci Total Environ 214:113-121

Lawson SL, Jones MB, Moate RM (1995) Effect of copper on the ultrastructure of the gill epithelium of Carcinus maenas (Decapoda: Brachyura). Mar Pollut Bull 31:63-72

Leung KMY, Taylor AC, Furness RW (2000) Temperaturedependent physiological responses of the dogwhelk $\mathrm{Nu}$ cella lapillus to cadmium exposure. J Mar Biol Assoc UK 80:647-660

Lozano I, Devoy RJN, May W, Andersen U (2004) Storminess and vulnerability along the Atlantic coastlines of Europe: analysis of storm records and of a greenhouse gases induced climate scenario. Mar Geol 210:205-225

Luoma SN (1983) Bioavailability of trace metals to aquatic organisms: a review. Sci Total Environ 28:1-22

Malins DC, Ostrander GK (1994) Aquatic toxicology: molecular, biochemical and cellular perspective. Lewis Publishers, Boca Raton, FL

Malvin GM (1998) Thermoregulatory changes by hypoxia: lessons from the paramecium. Clin Exp Pharmacol Physiol 25: $165-169$

Malvin GM, Havlen P, Baldwin C (1994) Interactions between cellular respiration and thermoregulation in the para- mecium. Am J Physiol 36:R349-R352

Mark FC, Bock C, Pörtner HO (2002) Oxygen limited thermal tolerance in Antarctic fish investigated by MRI and ${ }^{31} \mathrm{P}-$ MRS. Am J Physiol 283:R1254-R1262

> Martens P, Kovats RS, Nijhof S, de Vries P and others (1999) Climate change and future populations at risk of malaria. Glob Environ Change 9:S89-S107

- Martínez-Jerónimo F, Martínez-Jerónimo L, EspinosaChávez F (2006) Effect of culture conditions and mother's age on the sensitivity of Daphnia magna Straus, 1820 (Cladocera) neonates to hexavalent chromium. Exotoxicology 15:259-266

Massabuau JC, Tran D (2003) Ventilation, a recently described step limiting heavy metal contamination in aquatic animals. J Phys IV 107:839-843

McLeod JC, Pessah E (1973) Temperature effects on mercury accumulation, toxicity, and metabolic rate in the rainbow trout (Salmo gairdneri). J Fish Res Board Can 30:485-492

McLusky DS, Bryant V, Campbell R (1986) The effects of temperature and salinity on the toxicity of heavy metals to marine and estuarine invertebrates. Oceanogr Mar Biol Annu Rev 24:481-520

> Melzner F, Mark FC, Pörtner HO (2007) Role of blood-oxygen transport in thermal tolerance of cuttlefish, Sepia officinalis. Integr Comp Biol 47:645-655

Mitchelmore CL, Ringwood AH, Weis VM (2003) Differential accumulation of cadmium and changes in glutathione levels as a function of symbiotic state in the sea anemone Anthopleura elegantissima. J Exp Mar Biol Ecol 284:71-85

Moraitou-Apostolopoulou M, Verriopoulos G (1979) Some effects of sub-lethal concentrations of copper on a marine copepod. Mar Pollut Bull 10:88-92

Moraitou-Apostolopoulou M, Verriopoulos G, Rogdakis I (1982) Evaluation of the stress exerted by a polluted environment to a marine organism by comparative toxicity test. Bull Environ Contam Toxicol 28:416-423

> Moraitou-Apostolopoulou M, Kiortsis M, Verriopoulos V, Platanistioti S (1983) Effects of copper sulphate on Tisbe holothuriae Humes (Copepoda) and development of tolerance to copper. Hydrobiologia 99:145-150

> Morley NJ, Crane M, Lewis JW (2001) Toxicity of cadmium and zinc to Diplostomum spathaceum (Trematoda: Diplostomidae) cercarial survival. Int J Parasitol 31:1211-1217

Mubiana VK, Blust R (2007) Effects of temperature on scope for growth and accumulation of $\mathrm{Cd}, \mathrm{Co}, \mathrm{Cu}$ and $\mathrm{Pb}$ by the marine bivalve Mytilus edulis. Mar Environ Res 63: 219-235

> Naimo TJ, Atchinson GJ, Holland-Bartels LE (1992) Sublethal effects of cadmium on physiological responses in pocketbook mussel, Lampsilis ventricosa. Environ Toxicol Chem 11:1013-1021

> Nichols JW, Playle RC (2004) Influence of temperature on silver accumulation and depuration in rainbow trout. J Fish Biol 64:1638-1654

Nonnotte L, Boitel F, Truchot JP (1993) Waterborne copper causes gill damage and hemolymph hypoxia in the shore crab Carcinus maenas. Can J Zool 71:1569-1576

Occhipinti-Ambrogi A (2007) Global change and marine communities: alien species and climate change. Mar Pollut Bull 55:342-352

Odin M, Ribeyre F, Boudou A (1996) Temperature and $\mathrm{pH}$ effects on cadmium and methylmercury bioaccumulation by nymphs of the burrowing mayfly Hexagenia rigida, from water column or sediment source. Arch Environ Contam Toxicol 31:339-349

Paladino FV, Spotila JR (1978) The effect of arsenic on the thermal tolerance of newly hatched muskellunge fry (ESoX 
masquinongy). J Therm Biol 3:223-227

Parmesan C (2006) Ecological and evolutionary responses to recent climate change. Annu Rev Ecol Syst 37:637-669

> Peck LS, Webb KE, Bailey D (2004) Extreme sensitivity of biological function to temperature in Antarctic marine species. Funct Ecol 18:625-630

$>$ Pernet F, Tremblay R, Comeau L, Guderley H (2007) Temperature adaptation in two bivalve species from different habitats: energetics and remodelling of membrane lipids. J Exp Biol 210:2999-3014

Peterson RN (1976) Temperature selection of juvenile Atlantic salmon (Salmo salar) as influenced by various toxic substances. J Fish Res Board Can 33:1722-1730

> Phillips DJH (1976) The common mussel Mytilus edulis as an indicator of pollution by zinc, cadmium, lead and copper. II. Relationship of metals in the mussel to those discharged by industry. Mar Biol 38:71-81

Ponka P, Beaumont C, Richardson DR (1998) Function and regulation of transferrin and ferritin. Semin Hematol 35: $35-54$

Pörtner HO (2001) Climate change and temperature dependent biogeography: oxygen limitation of thermal tolerance in animals. Naturwissenschaften 88:137-146

Pörtner HO (2002) Climate variations and the physiological basis of temperature dependent biogeography: systemic to molecular hierarchy of thermal tolerance in animals. Comp Biochem Physiol A 132:739-761

Pörtner HO, Knust R (2007) Climate change affects marine fishes through the oxygen limitation of thermal tolerance. Science 315:95-97

Pörtner HO, Peck LS, Zielinski S, Conway LZ (1999) Intracellular $\mathrm{pH}$ and energy metabolism in the highly stenothermal Antarctic bivalve Limopsis marionensis as a function of ambient temperature. Polar Biol 22:17-30

Pörtner HO, Berdal B, Blust R, Brix O and others (2001) Climate induced temperature effects on growth performance, fecundity and recruitment in marine fish: developing a hypothesis for cause and effect relationships in Atlantic cod (Gadus morhua) and common eelpout (Zoarces viviparus). Cont Shelf Res 21:1975-1997

Pörtner HO, Peck LS, Hirse T (2006) Hyperoxia alleviates thermal stress in the Antarctic bivalve, Laternula elliptica: evidence for oxygen limited thermal tolerance. Polar Biol 29:688-693

Pörtner HO, Peck L, Somero G (2007) Thermal limits and adaptation in marine Antarctic ectotherms: an integrative view. Phil Trans R Soc Lond B 362:2233-2258

> Poulton BC, Beitinger TL, Stewart KW (1989) The effect of hexavalent chromium on the critical thermal maximum and body burden of Clioperla clio (Plecoptera: Perlodidae). Arch Environ Contam Toxicol 18:594-600

Rainbow PS (2007) Trace metal bioaccumulation: models, metabolic availability and toxicity. Environ Int 33:576-501

Rajotte JW, Couture P (2002) Effects of environmental metal contamination on the condition, swimming performance, and tissue metabolic capacities of wild yellow perch (Perca flavescens). Can J Fish Aquat Sci 59:1296-1304

Ramirez P, Barrera G, Carlos R (1989) Effects of chromium and cadmium upon respiration and survival of Callinectes similis. Bull Environ Contam Toxicol 43:850-857

Rao DGVP, Khan MAQ (2000) Zebra mussels: enhancement of copper toxicity by high temperature and its relationship with respiration and metabolism. Water Environ Res 72: 175-178

Rathore RS, Khangarot BS (2002) Effects of temperature on the sensitivity of sludge worm Tubifex tubifex Müller to selected heavy metals. Ecotoxicol Environ Saf 53:27-36
Reddy PS, Bhagyalakshmi A (1994) Changes in oxidative metabolism in selected tissues of the crab (Scylla serrata) in response to cadmium toxicity. Ecotoxicol Environ Saf 29:255-264

> Regoli F, Principato G (1995) Glutathione, glutathione-dependent and antioxidant enzymes in mussel, Mytilus galloprovincialis, exposed to metals in different field and laboratory conditions: implications for a proper use of biochemical biomarkers. Aquat Toxicol 31:143-164

Regoli F, Frenzilli G, Bocchetti R, Annarumma F, Scarcelli V, Fattorini D, Nigro M (2004) Time-course variations of oxyradical metabolism, DNA integrity and lysosomal stability in mussels, Mytilus galloprovincialis, during a field translocation experiment. Aquat Toxicol 68:167-178

Reid PC, Planque B, Edwards M (1998) Is observed variability in the long-term results of the Continuous Plankton Recorder survey a response to climate change? Fish Oceanogr 7:282-288

Ringwood AH, Conners DE, DiNovo A (1998) The effects of copper exposures on cellular responses in oysters. Mar Environ Res 46:591-595

Ringwood AH, Conners DE, Keppler CJ, Dinovo AA (1999) Biomarker studies with juvenile oysters (Crassostrea virginica) deployed in situ. Biomarkers 4:400-414

Roch M, Maly EJ (1979) Relationship of cadmium-induced hypocalcemia with mortality in rainbow trout (Oncorhynchus mykiss) and on metal binding to their gills. J Fish Res Board Can 11:1297-1303

Roesijadi G (1996) Metallothionein and its role in toxic metal regulation. Comp Biochem Physiol C 113:117-123

Roesijadi G, Robinson WE (1994) Metal regulation in aquatic animals: mechanisms of uptake, accumulation and release. In: Malins DC, Ostrander GK (eds) Aquatic toxicology: molecular, biochemical and cellular perspective. Lewis Publishers, Boca Raton, FL, p 387-420

> Roessig JM, Woodley CM, Cech JM Jr, Hansen LJ (2004) Effects of global climate change on marine and estuarine fishes and fisheries. Rev Fish Biol Fish 14:251-257

Roff DA (2002) Life history evolution. Sinauer, Sunderland, MA $>$ Rolfs A, Hediger MA (1999) Metal ion transporters in mammals: structure, function and pathological implications. J Physiol 518:1-12

> Rosas C, Ramirez P (1993) Effect of chromium and cadmium on the thermal tolerance of the prawn Macrobrachium rosenbergii exposed to hard and soft water. Bull Environ Contam Toxicol 51:568-574

Rosenzweig C, Casassa GD, Karoly DJ, Imeson A and others (2007) Assessment of observed changes and responses in natural and managed systems. In: Parry ML, Canziani OF, Palutikof JP, van der Linden PJ, Hanson CE (eds) Climate Change 2007: impacts, adaptation and vulnerability. Contribution of Working Group II to the 4th Assessment Report of the Intergovernmental Panel on Climate Change. Cambridge University Press, Cambridge, p 79-131

> Sanchez-Hernandez JC (2000) Trace element contamination in Antarctic ecosystems. Rev Environ Contam Toxicol 166: 83-127

Sanni B, Williams K, Sokolov EP, Sokolova IM (2007) Effects of acclimation temperature and cadmium exposure on mitochondrial aconitase and LON protease from a model marine ectotherm, Crassostrea virginica. Comp Biochem Physiol C 147:101-112

- Santos MHS, da Cunha NT, Bianchini A (2000) Effects of copper and zinc on growth, feeding and oxygen consumption of Farfantepenaeus paulensis postlarvae (Decapoda: Penaeida). J Exp Mar Biol Ecol 247:233-242

Sartoris FJ, Bock C, Serendero I, Lannig G, Pörtner HO (2003) 
Temperature dependent changes in energy metabolism, intracellular $\mathrm{pH}$ and blood oxygen tension in the Atlantic cod, Gadus morhua. J Fish Biol 62:1239-1253

Sibly RM, Calow P (1989) A life-cycle theory of responses to stress. Biol J Linn Soc 37:101-116

Sinensky M (1974) Homeoviscous adaptation-a homeostatic process that regulates the viscosity of membrane lipids in Escherichia coli. Proc Natl Acad Sci USA 71:522-525

Sokolova IM (2004) Cadmium effects on mitochondrial function are enhanced by elevated temperatures in a marine poikilotherm, Crassostrea virginica Gmelin (Bivalvia: Ostreidae). J Exp Biol 207:2639-2648

Somero GN (2005) Linking biogeography to physiology: evolutionary and acclimatory adjustments of thermal limits. Front Zool 2:1

Somero GN, de Vries AL (1967) Temperature tolerance of some Antarctic fishes. Science 156:257-258

Sommer AM, Pörtner HO (2002) Metabolic cold adaptation in the lugworm Arenicola marina: comparison of a North Sea and a White Sea population. Mar Ecol Prog Ser 240: 171-182

Spicer JI, Weber RE (1991) Respiratory impairment in crustaceans and molluscs due to exposure to heavy metals. Comp Biochem Physiol C 100:339-342

Spurgeon DJ, Svendsen C, Lister LJ, Hankard PK, Kille P (2005) Earthworm responses to $\mathrm{Cd}$ and $\mathrm{Cu}$ under fluctuating environmental conditions: a comparison with results from laboratory exposures. Environ Pollut 136:443-452

Stefaniak LM, McAtee J, Shulman MJ (2005) The costs of being bored: effects of a clionid sponge on the gastropod Littorina littorea (L). J Exp Mar Biol Ecol 327:103-114

Suresh A, Sivaramakrishna B, Radhakrishnaiah K (1993) Effect of lethal and sublethal concentrations of cadmium on energetics in the gills of fry and fingerlings of Cyprinus carpio. Bull Environ Contam Toxicol 51:920-926

Suzuki A, Gagan MK, Kan H, Edward A, Siringan FP, Yoneda M, Kawahata H (2007) Coral records of the 1990s in the tropical Northwest Pacific: ENSO, mass coral bleaching, and global warming, Chapter 9. Elsevier Oceanogr Ser 37: 211-238

> Sze PWG, Lee SY (1995) The potential role of mucus in the depuration of copper from the mussels Perna viridis (L.) and Septifer virgatus (Wiegmann). Mar Pollut Bull 31: 390-393

Toplan S, Ozcelik D, Dariyerli N, Akyolcu MC (2003) Oxidant and antioxidant status of cadmium administered rats. Journal de Physique IV 107:1309

Trenberth KE, Jones PD, Ambenje P, Bojariu R and others (2007) Observations: surface and atmospheric climate change. In: Solomon S, Qin D, Manning M, Chen Z, Marquis M, Averyt KB, Tignor M Miller HL (eds) Climate Change 2007: the physical science basis. Contribution of Working Group I to the 4th Assessment Report of the Intergovernmental Panel on Climate Change. Cambridge University Press, Cambridge, p 235-336

Tsui MK, Wang WX (2006) Acute, toxicity of mercury to Daphnia magna under different conditions. Environ Sci Technol 40:4025-4030

Ugedal O, Jonsson B, Njastad O, Naeuman R (1992) Effects of temperature and body size of radiocesium retention in brown trout (Salmo trutta). Freshw Biol 28:165-171

Valko M, Morris H, Cronin MT (2005) Metals, toxicity and oxidative stress. Curr Med Chem 12:1161-1208

van Straalen NM, Hoffmann AA (2000) Review of experimental evidence for physiological costs of tolerance to toxicants. In: Kammega JE, Laskowski R (eds) Demography in ecotoxicology. John Wiley \& Sons, Chichester, p 115-124

Viarengo A, Canesi L, Pertica M, Poli G, Moore MN, Orunesu M (1990) Heavy metal effects on lipid peroxidation in the tissues of Mytilus galloprovincialis Lam. Comp Biochem Physiol C 97:37-42

Vijayavel K, Gopalakrishnan S, Balasubramanian MP (2007) Sublethal effect of silver and chromium in the green mussel Perna viridis with reference to alterations in oxygen uptake, filtration rate and membrane bound ATPase system as biomarkers. Chemosphere 69:979-986

> Vinebrooke RD, Cottingham KL, Norberg J, Scheffer M, Dodson SI, Maberly C, Sommer U (2004) Impacts of multiple stressors on biodiversity and ecosystem functioning: the role of species co-tolerance. Oikos 104:451-457

> Waiwood KG, Beamish FHW (1978) Effects of copper, pH and hardness on the critical swimming performance of rainbow trout (Salmo gairdneri Richardson). Water Res 12: 611-619

Walker CH, Hopkin SP, Sibly RM, Peakall DB (2001) Principles of ecotoxicology, 2nd edn. Taylor \& Francis, New York

Wallace KB, Starkov AA (2000) Mitochondrial targets of drug toxicity. Annu Rev Pharmacol Toxicol 40:353-388

> Wallace WG, Lopez GR (1996) Relationship between subcellular cadmium distribution in prey and cadmium trophic transfer to a predator. Estuaries 19:923-930

Wallace WG, Lopez GR (1997) Biovaliability of biologically sequestered cadmium and the implications of metal detoxification. Mar Ecol Prog Ser 147:149-157

> Wallace WG, Luoma SN (2003) Subcellular compartmentalization of $\mathrm{Cd}$ and $\mathrm{Zn}$ in two bivalves. II. Significance of trophically available metal (TAM). Mar Ecol Prog Ser 257: 125-137

Wallace WG, Lee BG, Luoma SN (2003) Subcellular compartmentalization of $\mathrm{Cd}$ and $\mathrm{Zn}$ in two bivalves. I. Significance of metal-sensitive fractions (MSF) and biologically detoxified metal (BDM). Mar Ecol Prog Ser 249:183-197

Wang J, Chuang CY, Wang WX (2005) Metal and oxygen uptake in the green mussel Perna viridis under different metabolic conditions. Environ Toxicol Chem 24:2657-2664

Weber RE, Vinogradov SN (2001) Nonvertebrate hemoglobins: functions and molecular adaptation. Physiol Rev 81: 569-618

> Weber RE, Lykke-Madsen M, Bang A, De Zwaan A, Cortesi P (1990) Effects of cadmium on anoxic survival, haematology, erythrocytic volume regulation and haemoglobinoxygen affinity in the marine bivalve Scapharca inaequivalvis. J Exp Mar Biol Ecol 144:29-38

Weihe WH (1973) The effect of temperature on the action of drugs. Annu Rev Pharmacol 13:409-425

Williams E, Somero G (1996) Seasonal-, tidal-cycle- and microhabitat-related variation in membrane order of phospholipid vesicles from gills of the intertidal mussel Mytilus californianus. J Exp Biol 199:1587-1596

Willmer P, Stone G, Johnston I (2000) Environmental physiology of animals. Blackwell Science, Oxford

Wilson RS, Kuchel LJ, Franklin CE, Davison W (2002) Turning up the heat on subzero fish: thermal dependence of sustained swimming in an Antarctic notothenioid. J Therm Biol 27:381-386

Wilson RW, Taylor EW (1993) The physiological responses of freshwater rainbow trout, Oncorhynchus mykiss, during acutely lethal copper exposure. J Comp Physiol B 163: $38-47$

Witeska M, Jezierska B (2003) The effect of environmental factors on metal toxicity to fish. Fresen Environ Bull 12: 824-829

Wood LA, Brown IA, Youson JH (1999) Tissue and develop- 
mental variations in the heat shock response of sea lampreys (Petromyzon marinus): effects of an increase in acclimation temperature. Comp Biochem Physiol A 123:35-42

> Worms I, Simon DF, Hassler CS, Wilkinson KJ (2006) Bioavailability of trace metals to aquatic microorganisms: importance of chemical, biological and physical processes on biouptake. Biochimie 88:1721-1731

Yang FY, Hwang F (1996) Effect of non-bilayer lipids on the

Submitted: November 2, 2007; Accepted: April 29, 2008 activity of membrane enzymes. Chem Phys Lipids 81: 197-202

Yang HN, Chen HC (1996) Uptake and elimination of cadmium by Japanese eel, Anguilla japonica, at various temperatures. Bull Environ Contam Toxicol 56:670-676

Zalups RK, Ahmad S (2003) Molecular handling of cadmium in transporting epithelia. Toxicol Appl Pharmacol 186: 163-188

Proofs received from author(s): September 15, 2008 